\title{
Soy Transition- Ethiopia and The Netherlands
}

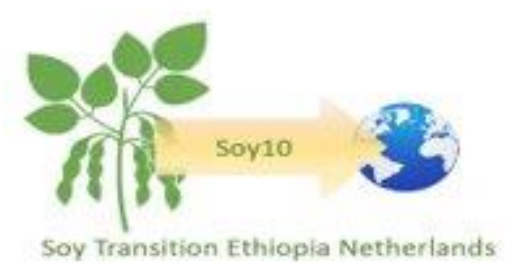

Judit Snethlage ${ }^{1}$, Remko Vonk ${ }^{1}$, Ponraj Arumugam ${ }^{1}$, Sjaak Conijn ${ }^{2}$, Marleen Hermelink ${ }^{2}$, Fulco Ludwig ${ }^{3}$, Iwan Supit ${ }^{3}$ Sneha Chevuru ${ }^{3}$

1 Wageningen Environmental Research

2 Wageningen Plant Research

3 Wageningen University

This research was subsidised by the Protein Transition Fund (KB-39) (Project number: 3720021400)

Wageningen Environmental Research

Wageningen, December 2021 
Keywords: Protein transition, Ethiopia future protein, Netherlands future protein

The pdf file is free of charge and can be downloaded at https://doi.org/10.18174/560794 or via the website www.wur.nl/environmental-research (scroll down to Publications - Wageningen Environmental Research reports). Wageningen Environmental Research does not deliver printed versions of the Wageningen Environmental Research reports.

CC-BY license

(0) 2022 Wageningen Environmental Research (an institute under the auspices of the Stichting Wageningen Research), P.O. Box 47, 6700 AA Wageningen, The Netherlands,

$\mathrm{T}+31$ (0)317 4807 00, www.wur.nl/environmental-research. Wageningen Environmental

Research is part of Wageningen University \& Research.

Wageningen Environmental Research assumes no liability for any losses resulting from the use of the research results or recommendations in this report. 


\section{Contents}

$\begin{array}{ll}\text { Summary } & 6\end{array}$

$\begin{array}{ll}\text { Acknowledgements } & 7\end{array}$

$1 \quad$ Introduction Project Context $\quad 8$

$2 \quad$ Case Ethiopia $\quad 9$

2.1 Introduction Case Ethiopia 9

2.2 Approach Case Ethiopia 11

$3 \quad$ Diet Ethiopia 13

$4 \quad$ Modelling Ethiopia $\quad 14$

4.1 Land Use 14

4.2 Water Use 17

$5 \quad$ Other Indicators: Greenhouse Gas Emissions and Nutrient Losses 20

$6 \quad$ Case The Netherlands $\quad 23$

6.1 Introduction Case The Netherlands 23

6.2 Approach Case The Netherlands $\quad 24$

$\begin{array}{lll}6.3 & \text { Water-Limited Production } & 26\end{array}$

$\begin{array}{lll}6.4 & \text { Potential Production } & 26\end{array}$

$\begin{array}{llr}7 & \text { Diet Netherlands } & 27\end{array}$

$8 \quad$ Modelling Netherlands $r$

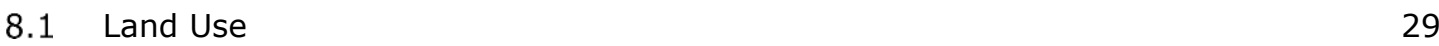

$\begin{array}{ll}8.2 \text { Water Use } & 31\end{array}$

$9 \quad$ GHG Emissions and NH3 Emissions $\quad 34$

10 Reflection $\quad 36$

10.1 Ethiopia Case Summary and Reflections 36

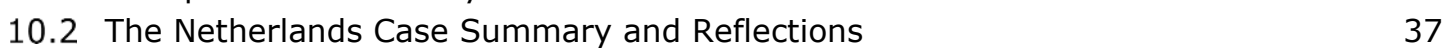

10.3 Similarities and Difference between Protein Transition in Ethiopia and The Netherlands $\quad 38$

$\begin{array}{ll}10.4 \text { General Reflections } & 39\end{array}$

$\begin{array}{lll}10.5 & \text { Follow-Up Research } & 39\end{array}$

$\begin{array}{lr}\text { References } & 41\end{array}$

$\begin{array}{lll}\text { Annex } 1 & \text { Food Balance Sheet (FAO) } & 44\end{array}$

Annex 2 Diet, Production, and Land Use (Ethiopia, 2017) 45

Annex 3 Crop Yield Maps (Ethiopia, 2017) 46

Annex 4 Alternative Method for Land Use of Soybean (Ethiopia, 2017) 47 
Annex 5 Diet and Production (The Netherlands, 2015)

Annex 6 Soy and Feed Crop Parameters (The Netherlands, 2015) 50

Annex 7 Greenhouse Gas Emission Parameters (The Netherlands) 51

Annex 8 IPCC N Calculations

52 


\section{Summary}

This study looks at the potential of using soy to support a plant-based protein transition in the Netherlands and Ethiopia. These two countries represent two very different socio-economic contexts and have contrasting starting points for a potential protein transition. Currently, the Dutch diet is high in protein and mainly consumed via meat and milk. Ethiopia's subsistenceoriented agriculture on the other hand is largely based on cereal crops, resulting on average in a low protein diet.

For the research, the impacts of hypothetical protein transition are calculated. Ten percent of the protein consumed through cereal was replaced by soy protein for Ethiopia. For the Dutch case ten percent of the cow milk protein was interchanged by ten percent of soy protein drink. The effect of the soy protein transition is calculated for greenhouse gas emissions, water, and land use changes. The calculations were done with a mixed approach. The models WOFOST and Global LPJML combined with literature review.

Despite the different contexts of both countries, some similarities arise in the conclusion. For both nations interchanging ten percent of protein consumption to soy protein will result in a reduction of land use. Both countries currently experience a great pressure on land use. Replacing a small part of the protein to soy will therefore be considered as a positive development. In addition, overall small impacts on the other indicators a consequence of the transition. Nonetheless, differences also have been found which focus mostly on the impact on diet and climate change. While in the Netherlands overconsumption of calories and fat is becoming a problem, Ethiopia still encounters areas with food insecurity. A decline therefore in fat and calories due to the soy protein transition is a beneficial effect for the Netherlands. However, in Ethiopia this would not be the case. With respect to climate change, in Ethiopia it seems the yields will increase for soy. A changing climate is expected to be more favorable for growing soy in Ethiopia. In the Netherlands, the soy yield will increase but with less protein content and higher fat content. This could counter the aforementioned initial positive impact of decreasing fat. Follow-up research is needed on both further developing the methodology and calculating other hypothetical scenarios. 


\section{Acknowledgements}

The authors of this report would like to thank the protein transition fund (KB-39) of WUR for their support and funding. 


\section{Introduction Project Context}

The world population is growing, the climate is changing, and large parts of the world are entering a new level of welfare. This increase in welfare leads to different dietary demands and these changes lead to different impacts on the environment and on human health. Overall, it can be said that an increase in welfare leads to an increase in protein demand. If this increase of protein would only come from animal proteins, more resources are needed compared to using plant proteins. Also, improved health impacts could result from using more plant proteins instead of animal proteins. That is why other sources of protein could be favorable in terms of environment or health. Soy is one of the potential crops for plant protein in the human diet. Research has been done on various topics in the context of soy. The current focus of some studies is on specific effects of soy on the environment. Some studies combine more than one factor (e.g., diet and GHG emissions) on studying the impact of soy on the environment (Tallentire et al., 2018). However, an integral combination of environment and some aspects of health, is relatively unknown. Generally, the studies have focussed on one aspect of the impact of soy on the environment and/or health. Also, all the studies have different approaches in calculating impact on the environment and aspect of diet. With this study we want to explore a more integrative approach towards calculating the impacts of a protein transition. We used soy as a proxy for our calculations/assessment of the impacts of a transition for the following reasons. First, soy is already used in many meat replacements and therefore it is a realistic choice for a potential transition. Secondly, there is a lot of data on soy production and consumption. Thirdly, soy is a high protein crop. As we look at a protein shift, this is an important indicator for a crop.

This study looks at the potential of using soy for food to support a plant-based protein transition in The Netherlands and Ethiopia. These two countries represent two very different socio-economic contexts and have very different starting points for a potential protein transition. The Dutch context is a high current consumption of animal protein mainly via meat and milk (Dagevos et al., 2018). Also, there is a wide belief that shifting from a protein-rich animal-based diet to a more plant-based diet is healthier and more environmentally friendly (FAO,2010) (WHO, 2020). On the other hand, Ethiopia's subsistence-oriented agriculture is largely based on cereal crops and the average diet is very low in protein. The stimulation of a high-quality protein rich crop like soy, rather than meat, could have a significant impact on the nutrition status of the people and on the environment.

The research will deliver insights in the impact of a plant-based protein transition on Greenhouse Gas (GHG) emissions, some (other) aspects of the environment and some aspects of diet in The Netherlands and Ethiopia. Most of the calculations will be done for 3 scenarios, current situation, current situation with $10 \%$ of the protein transition and a future climate situation with $10 \%$ of the protein transition. At the end of the study there will be more insights in the impacts on the environment (including climate) and nutrition of the transition to soy consumption in both countries, looking at specific indicators. Moreover, there will be a reflection on using soy as a proxy for other possible plant protein transitions. In this way we want to develop an approach for more integrated analyses when reflecting on certain protein transition.

The structure of the report follows first the of the case of Ethiopia is discussed and then the case of the Netherlands is presented. At the end some reflections are presented on both cases and follow up research. 


\section{Case Ethiopia}

\subsection{Introduction Case Ethiopia}

To understand a possible impact of a protein transition, first the current situation needs to be understood. The main research objective for this research is that we investigated the consequences of replacing $10 \%$ of the current cereal protein intake with protein intake from soy. To guide the research, specific research questions are formulated for this case. First the main research questions are presented and afterwards a short introduction into the context of the diet and soy in Ethiopia.

\section{Specific research questions:}

- How would a $10 \%$ transition of protein affect dietary energy and fat intake?

- How would a $10 \%$ transition of protein source from cereals to soybean affect land use in Ethiopia?

- How would the water balances (precipitation deficit/surplus and irrigation) be affected by the $10 \%$ transition in protein source with or without projected climate change?

- How would the greenhouse gas emission change by the protein transition?

- How much fertilizer use would change by the protein transition?

\section{Context case}

Ethiopia, as the rest of the world, is facing the ramifications of climate change. This could have a great impact on its food and water security. As Ethiopia is largely a water supplier to its neighbouring countries, water availability within Ethiopia can impact water and food security in the East African region, including Sudan and Egypt. It is therefore of great importance to gain a better understanding on the possible developments in Ethiopia with regards to its food and water availability, and of the nexus existing between these two essential resources. Food insecurity, because of frequent droughts, among other reasons, is high. The prevalence of undernourishment is still significant with $35 \%$ in 2014, falling from $55 \%$ in 2002 (FAO, 2015). About $10 \%$ of the households are still considered food insecure and partly rely on food aid even without dry spells (Hermelink and Conijn, 2021) (FAO,2016).

\section{Context current diet}

Over the last 50 years the caloric supply has increased from $1710 \mathrm{kcal} / \mathrm{d}$ to $2111 \mathrm{kcal} / \mathrm{d}$ (Sheehy et al., 2019). The largest source of energy supply are carbohydrates covering at least $70 \%$ of the dietary energy. The energy from fat was low and varied between 10 and $14 \%$ (Sheehy et al., 2019). Energy from proteins contributed between 11-14\% over these years (Sheehy et al., 2019). Per capita supplies of calcium, vitamin A, C, D, folate, and other B-vitamins were insufficient and there is a low supply of animal foods (Sheehy et al., 2019).

Soybean serves both as source of protein (c.a. 40\%) and oil (c.a. 20\%). The amino acid balance of soybean is close to that of milk and meat. Globally, soybean ranks second as major oil crop after oil palm. Furthermore, soybean is a source of healthy fatty acids such as lecithin and vitamins such as vitamin A and D. Soy drink can also fetch a market during vegan (over 200 days of fasting animal products) among Ethiopian Orthodox Christians. In addition, soybean contains a high concentration of special amino acids and iso-flavon, which are essential in building the human immune system.

\section{Context soy}

The introduction of soybean into Ethiopia is associated with establishment of the Jimma Agricultural Technical School (JATS) in 1952, when staff of the Oklahoma State University, working for JATS, tested the suitability of the crop in Jimma area. It was then concluded 
that soybean is suitable to the southwestern part of Ethiopia and has the same agro-ecological characteristics as maize. Further expansion of soybean production in Ethiopia was promoted through the based German oil seeds research project (Bako), and by state- owned commercial farms in 1970s and 1980s as well as recent commercial farmers in western and southern parts of the country (Tesfaye et al., 2018). Similarly, data from Central Statistics Agency 2017 indicates that soybean production in Ethiopia increased from 8,401 ton in 2007 to 81,235 ton in 2016 from smallholder farmers. Most of the soy is cultivated in Oromia, Benshangul Gumuz and Amhara regional states (Figure 1), accounting for $99 \%$ of the production (Jimma, Illubabor and Wollega zones of Oromia; Metekel, Assosa and Pawe zones of Benshangul Gumuz and Awi, east and west Gojjam zones of Amhara) (Hambis and Geda, 2019). Even though official quantitative data is lacking, much more soybean is produced by private commercial farms than by smallholder farmers. It is interesting to note that the commercial farms largely operate in Gambella, Benshangul Gumuz and western Oromia. The major commercial farms include Saudi Star PLC, Ethio-Agri-CEFT, and Ruchi agro-industry and other domestic private farms. Both under smallholder and commercial farms, the increase of soybean production is due to increased demand from food processing and animal feed producers (e.g., poultry feed). More recently, expansion of the area of production and increased productivity (per ha) have contributed to increased soybean production in Ethiopia. (Tesfaye and Berecha, n.d.)

Soybean is adapted to western, southern, and north-western parts of Ethiopia. Soybean shares the same growing areas with maize and the two crops can be grown in rotation. In symbiotic association with a rhizobium bacterium, soybean can fix atmospheric nitrogen, thereby contributing to soil nitrogen fertility.

Soybean is an important raw material for food and feed processing industries and has promising potential for the export market. Ethiopia has a potential to compete for genetically modified organisms (GMO) free soybean and its products in the world market as produce and products of soybean of major producers are mostly originating from genetically modified soy. As noted above soybean research was started at the former Jimma Agricultural Technical School (today's College of Agriculture of Jimma University) in early 1950s. Nationally coordinated soybean research started in 1967 at Hawassa Agricultural Research Center, which was then under the Institute of Agricultural Research. The main objective of the soybean research has been to meet domestic demand for food fortification and animal feed, and it has been less for export market. The main research centres involved in soybean improvement include Hawassa, Bako, Pawe, and Jimma. Soybean variety development targets three maturity groups: early, medium and late maturity groups. Until 2016, a total of 26 improved soybean varieties have been released for production by the abovementioned research centres as well as Areka and Sirinka Agricultural Research centres (Figure 1) (Desissa, 2019)

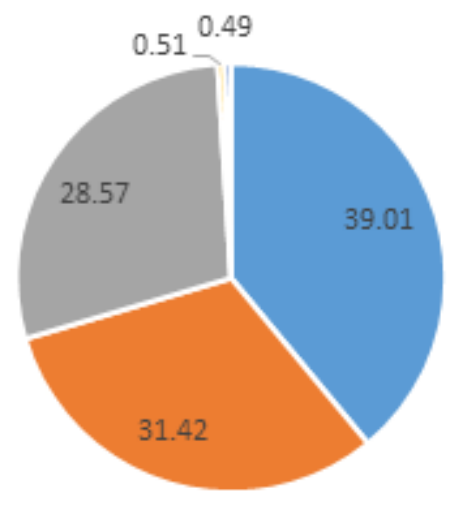

- Oromia " BenshangulGumuz "Amhara " SNNPR " Tigray

Figure 1 Major soybean producing states in Ethiopia (based on smallholder farming) ( $\%$ of production in ton) (Tesfaye and Berecha, n.d.) 


\subsection{Approach Case Ethiopia}

For answering the specific research questions on how much impact a protein transition could have on the environment and diet, we selected several indicators. These indicators are based on an arbitrary choice of some environmental aspects and diet. In table 1 the indicators are presented for the Ethiopia case.

Table 1 Selected indicators for environment and diet in Ethiopia (at national level)

\begin{tabular}{|cl|}
\hline \multicolumn{2}{|l|}{ Indicators } \\
\hline$\bullet$ & Dietary energy intake (kcal/capita) \\
\hline - & Land use for food production (ha) \\
\hline - & Agricultural total evaporation and runoff (m3) \\
\hline - & Agricultural fertilizer use (ton $\mathrm{N}$ ) \\
\hline - & Greenhouse gas emission (ton C02 equivalent) \\
\hline
\end{tabular}

In the following tables, for each indicator it is explained which data and approach is used for the modelling and for which scenario ( $A, B$ and $C$ ). Table 2 presents the indicators and table 3 presents the data sources for the analysis.

Table 2 Selected indicators for Ethiopia
Scenario
Baseline (A)
$10 \%$ Current (B)
$10 \%$ Future (C)

\begin{tabular}{|c|c|c|c|}
\hline & $\begin{array}{l}\text { Current diet, } \\
\text { Current climate, } \\
\text { year (2017) }\end{array}$ & $\begin{array}{l}10 \% \text { protein } \\
\text { transition, current } \\
\text { climate }\end{array}$ & $\begin{array}{l}10 \% \text { protein transition, future } \\
\text { climate }\end{array}$ \\
\hline Diet & \multicolumn{2}{|l|}{ kcal, fat } & (same diet as in $10 \%$ Current) \\
\hline Production & \multicolumn{3}{|c|}{ Yield and total production of cereals and soy } \\
\hline Land use & \multicolumn{2}{|c|}{ Harvested areas of cereals and soy } & (same as in $10 \%$ Current) \\
\hline Water use & \multicolumn{3}{|c|}{$\begin{array}{l}\text { Difference Precipitation -EvapoTranspiration } \\
\text { \& irrigation }\end{array}$} \\
\hline GHGemissions & \multicolumn{2}{|l|}{ N2O emissions } & (same as in $10 \%$ Current) \\
\hline $\begin{array}{l}\text { Agriculture } \\
\text { fertilizer use }\end{array}$ & \multicolumn{2}{|c|}{$\mathrm{Kg}$ of $\mathrm{N}$ organic and inorganic fertilizer } & (same as in $10 \%$ current) \\
\hline
\end{tabular}

Table 3 Data sources indicators Ethiopia
Scenario
Baseline (A)
$10 \%$ Current (B)
$10 \%$ Future (C)
Current diet, Current climate year $=2017$ $10 \%$ protein transition, current climate $10 \%$ protein transition, future climate 


\begin{tabular}{|c|c|c|c|}
\hline Diet & \multicolumn{2}{|c|}{ Food Balance Sheets of FAO } & $\begin{array}{l}\text { (same diet as in } 10 \% \\
\text { Current) }\end{array}$ \\
\hline Production & FAOSTAT & FAOSTAT, LPJmL & LPJmL \\
\hline Land use & MAPSPAM & MAPSPAM & (same as in $10 \%$ Current) \\
\hline Water use & \multicolumn{3}{|l|}{ LPJmL } \\
\hline GHG emissions & \multicolumn{2}{|l|}{ IPCC, } & (same as in $10 \%$ Current) \\
\hline $\begin{array}{l}\text { Agriculture } \\
\text { fertilizer use }\end{array}$ & \multicolumn{2}{|l|}{ IPCC } & (same as in $10 \%$ Current) \\
\hline
\end{tabular}




\section{Diet Ethiopia}

The diet is the starting point for implementing the protein transition from cereal protein towards soy protein. For the diet (change) and its relationship with production, data on cereals and soybean from the Food Balance Sheet (FBS) of the FAO for Ethiopia in 2017 have been used in this project. In the FAO databases the crop group cereals consist of the following cereal crops: Wheat, Rice (paddy), Maize, Barley, Millet, Sorghum, Oats and Other Cereals (not else specified). The FBS gives information about the national food supply which refers to available food including eventual food loss at the consumer's level (Annex 1 and 2). To estimate protein intake values, the food protein supplies of cereals and soybeans from the FBS were combined with food loss estimations in household and retail for Sub-Saharan Africa (SSA; Gustavsson et al., 2011). In the protein transition scenario, the protein intake of cereals is assumed to be reduced with $10 \%$ and this reduction in protein intake is replaced by the same (absolute) amount from soybeans. This amounts to a reduction of $4.2 \mathrm{~g} / \mathrm{capita} /$ day of cereal food protein supply and an identical increase in soybean food protein supply (due to the same loss fractions for cereals and pulses in Gustavsson et al., 2011). Due to the difference in current supplies between cereals and soybeans, the $10 \%$ reduction for cereals "causes" an increase of almost 13 times in the soybean protein supply (Annex 2, Table 2.1).

Based on the FBS, the change in protein intake (less from cereals, more from soybean) leads to a higher fat intake $(+1.3 \mathrm{~g} / \mathrm{capita} /$ day $)$ and a lower food energy intake $(-120 \mathrm{kcal} / \mathrm{capita} /$ day $)$ from cereals and soybean together. For a better overview, it is also summarized in table 4 .

Table 4 Overview of the cereal and soybean food supply in Ethiopia in scenarios A and B.

\begin{tabular}{|l|l|l|l|l|}
$\begin{array}{l}\text { Ethiopia, } \mathbf{2 0 1 7} \text { (Food Balance } \\
\text { sheet) }\end{array}$ & Cereals & & \multicolumn{2}{l|}{ Soybean } \\
\hline Element & Baseline & $\mathbf{1 0 \%}$ Current & Baseline & $\mathbf{1 0 \%}$ Current \\
\hline Fat supply (g/cap./day) & 6.67 & 6.00 & 0.17 & 2.15 \\
\hline Protein supply (g/cap./day) & 41.84 & 37.66 & 0.36 & 4.54 \\
\hline Food supply (kcal/cap./day) & 1553 & 1398 & 3 & 38 \\
\hline
\end{tabular}




\section{Modelling Ethiopia}

In this part the indicators that have been modelled are discussed. First a brief context of the indicator is given and afterwards the modelling process is described with output.

\subsection{Land Use}

\section{Context}

Ethiopia is the second-most populous nation in Africa with a population of 112 million people in 2019, Ethiopia. Also, it is the fastest growing economy in the region (Food and land use coalition, n.d) These developments lead to high pressure on the current. In figure 2 different land use types are shown, where agriculture is widespread in the western half of the country from North to South, whereas a very small part is used for settlements.

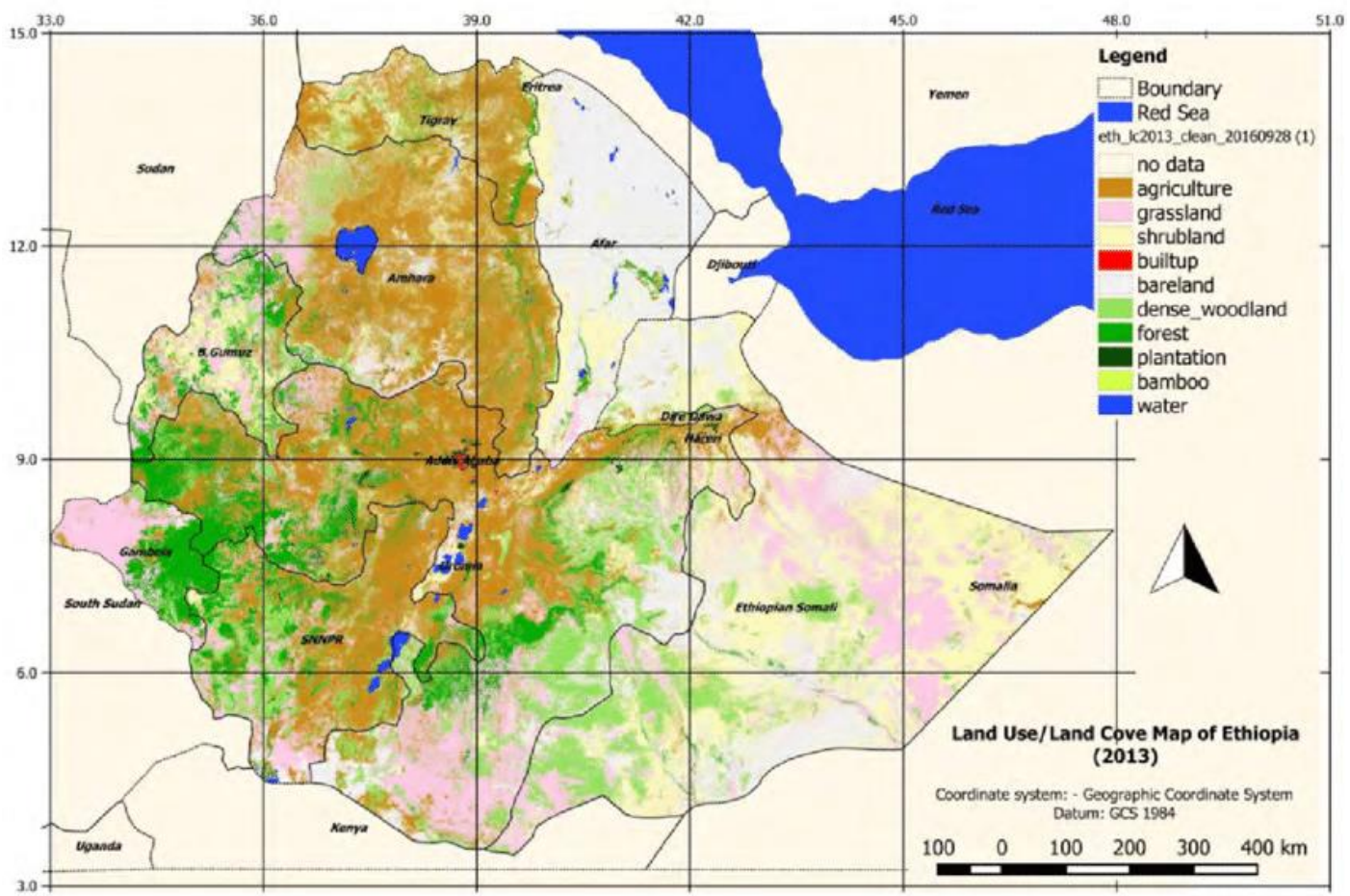

Figure 2 Dominant Land use/land cover map of Ethiopia (2013). Note: 11 categories are shown. "Forest" consists of high forest and riverine forest (Bekele et al., 2019)

Arable land use increased from $10 \%$ to $15 \%$ of total land area in the period $1994-2012$ (Figure 2). Also irrigated land and land under permanent crops increased as well as total agricultural land, which includes permanent grasslands. Both irrigated and permanent crop land use are quite small compared to total land use. Despite increasing arable land, the amount of arable land in hectares per person remained relatively stable, due to the relative larger population growth compared to arable land increase. 


\begin{tabular}{|c|c|c|c|c|c|c|c|}
\hline & 1994 & 1999 & 2004 & 2009 & 2010 & 2011 & 2012 \\
\hline $\begin{array}{l}\text { Agricultural land (\% of land } \\
\text { area) }\end{array}$ & 30.47 & 30.68 & 31.61 & 34.51 & 34.99 & 35.68 & 36.49 \\
\hline Arable land ( $\%$ of land area) & 9.93 & 10.00 & 10.93 & 13.61 & 13.95 & 14.57 & 15.35 \\
\hline $\begin{array}{l}\text { Arable land (hectares per } \\
\text { person) }\end{array}$ & 0.18 & 0.16 & 0.15 & 0.16 & 0.16 & 0.16 & 0.17 \\
\hline $\begin{array}{l}\text { Agricultural irrigated land (\% of } \\
\text { total agricultural land) }\end{array}$ & & & 0.38 & 0.48 & 0.44 & 0.51 & \\
\hline $\begin{array}{l}\text { Permanent cropland (\% of land } \\
\text { area) }\end{array}$ & 0.54 & 0.68 & 0.68 & 0.91 & 1.04 & 1.12 & 1.14 \\
\hline
\end{tabular}

Figure 3 Arable land and land under permanent crops (WDI,2014)

\section{Modelling}

Land use changes have been approximated in this study by estimating production differences due to the protein shift. Using the methodology of the FBS, differences in the production of cereals and soybeans were calculated as follows. The food supply, in 1000 tonnes per year, was found by applying the ratio between food and protein supplies (as apparent in the data from the FBS) to the new protein supplies in the protein transition scenario. Furthermore, food loss during storage and transportation has been determined as fraction of the sum of all utilization categories (Feed, Seed, Processing, Other uses, Residuals and Food), where all categories, except food, were kept identical to the FBS data of 2017 (Annex 2, Table 2.1).

In the protein transition scenario, the production of cereals is reduced with almost 1900 ktonnes per year $(-7.3 \%)$ and that of soybeans is increased with 501 ktonnes per year $(+510 \%)$.

These production differences have been combined with crop maps from MAPSPAM (IFPRI, 2020) to develop adjusted crop area maps for the protein transition scenario that are consistent with the above changes in cereal and soybean production. We downloaded MAPSPAM data on harvested area, production, and yield of all cereals (except Oats) and soybeans ${ }^{1}$.Cereal maps for harvested area and production were calculated by summing all individual cereals, and the cereal yield map was determined through dividing the production by the harvested area for each raster cell (see Figure 5 for harvested areas in 2017). Total national production of cereals in 2017 equalled 25500 ktonnes and that of soybeans 87 ktonnes, according to these maps, and the overall average crop yields amounted to 2.5 and 2.3 tonnes/ha, respectively (see Annex 3, for the yield maps of cereals and soybeans in 2017).

\footnotetext{
${ }^{1}$ SPAM 2017 V2.1 SSA containing raster maps with a resolution of 5 arcminutes
} 

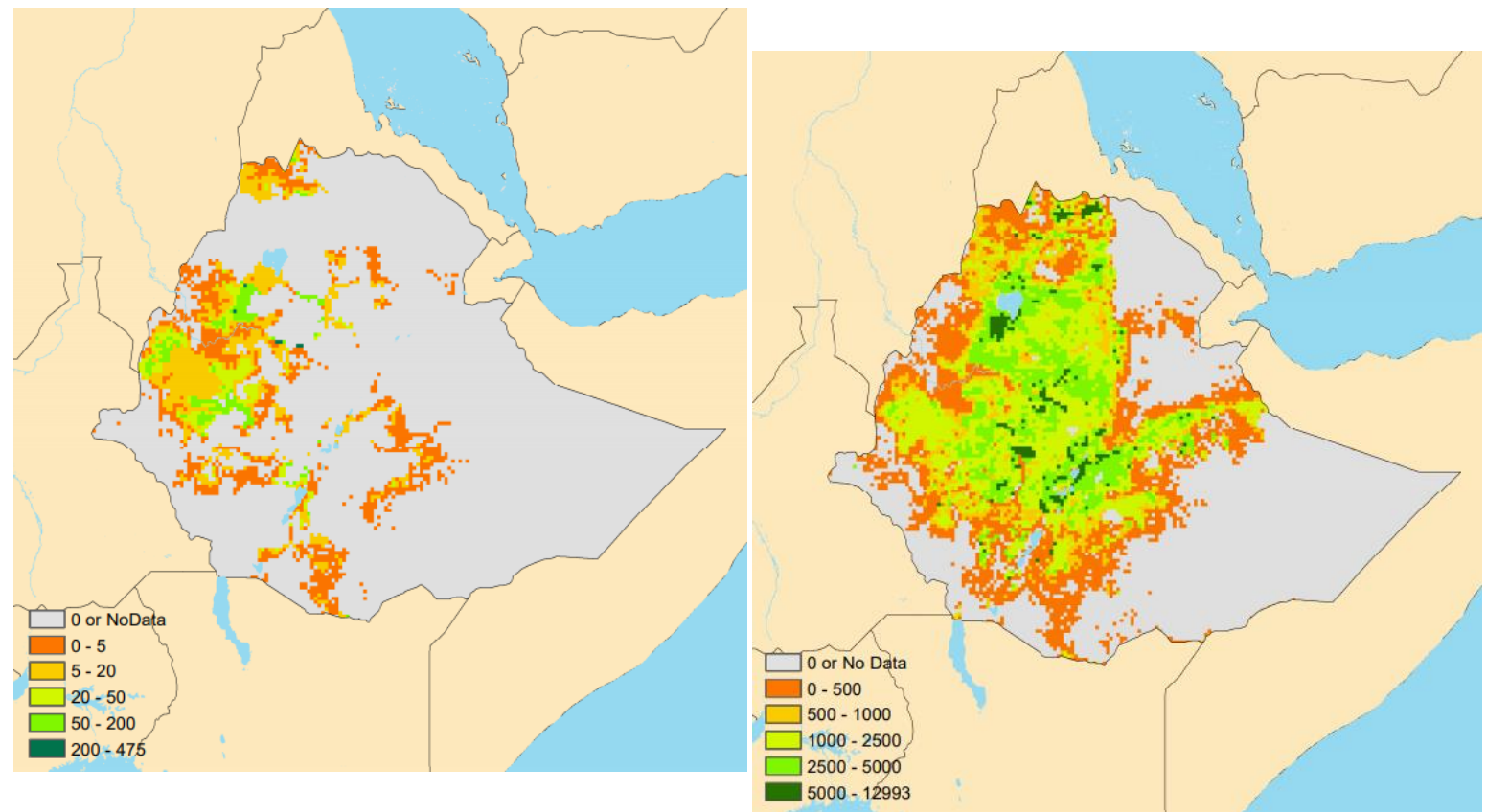

Figure 4 Harvested areas of soybean (left) and cereals (right) in ha per raster cell in 2017 ( 5 arcminute cell area equals approx. 8000 ha).

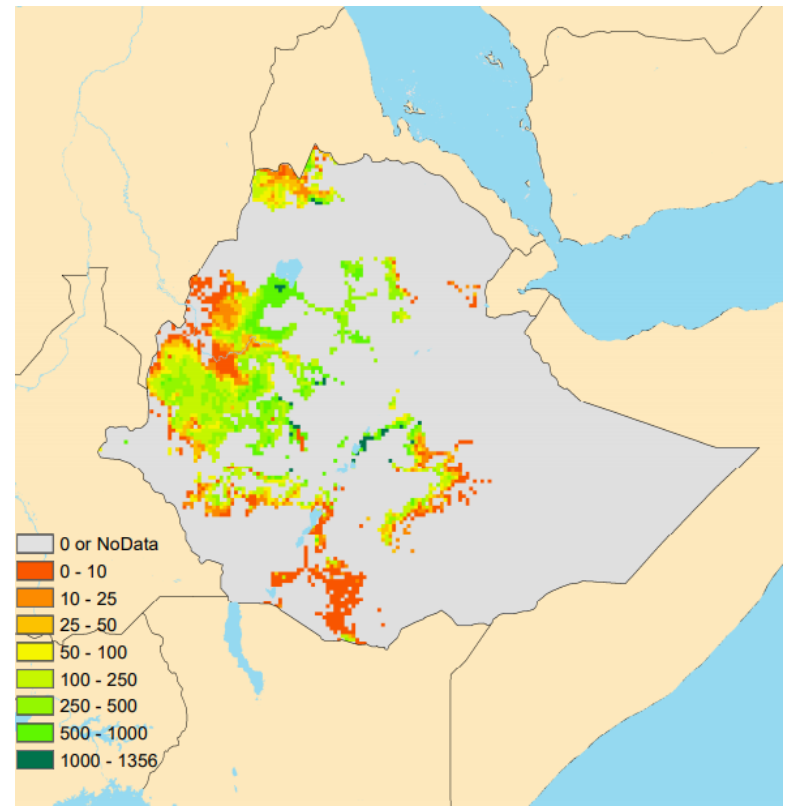

Figure 5 Difference between total land use of cereals and soybean in 2017 and the land use after $\mathbf{1 0} \%$ protein adjustment in ha per raster cell. All values are positive and indicate land use surpluses in each raster cell of the protein transition scenario

We have applied the production changes in the protein transition scenario only in raster cells that contain both cereals and soybeans in 2017 (according to MAPSPAM data). Total production of cereals and soybeans in this subset amounts to 7100 and 87 ktonnes per year, respectively, which equals $28 \%$ and nearly $100 \%$ of the total national production of these crops in 2017 . The high value for soybeans indicates that where soybeans are grown, also cereals are grown in the same raster cell. An adjusted harvested area map for cereals has been constructed by multiplying a change fraction (1900/7100 or 0.734; Annex 2, Table 2.2) with the "original" (2017) harvested cereal area in the subset of raster cells (all other cells remain unchanged). This method mimics the situation in which a farmer grows less cereals and uses part of the former cereal area to grow soybeans and implicitly assumes that the production conditions per ha in the protein transition 
scenario are not different from the original situation in 2017. Aggregated for the whole country will yield the total production of soybean as determined for the protein transition scenario.

National harvested area in the protein transition scenario is reduced by almost 485,000 ha relative to the situation in $2017(-4.7 \%$ of the area for cereals and soybeans and $-2.9 \%$ of the total harvested crop area in 2017), as a result of $-805,000$ ha for cereals and $+320,000$ ha for soybeans. However, the consequences for land use at individual cell level differs widely, due to differences in the original land used by cereals and soybeans in 2017 (Figure 5).

We can summarize the following points from the information in table 5 and bullet points.

Table 5 Land use change based on the transition of production from cereals to soy

\begin{tabular}{|l|l|l|l|l|}
\hline Production and area & Cereals & & Soybeans \\
\hline Element & Baseline & $\mathbf{1 0 \%}$ Current & Baseline & $\mathbf{1 0 \% C u r r e n t ~}$ \\
\hline Food (ktonnes/y) & 18271 & 16444 & 37 & 470 \\
\hline Production (ktonnes/y) & 25884 & 23996 & 98.3 & 599 \\
\hline Harvested area (kha) & 3026 & 2220 & 38.4 & 360 \\
\hline Difference (kha) & & $\mathbf{- 8 0 5}$ & & $\mathbf{+ 3 2 1}$ \\
\hline
\end{tabular}

\subsection{Water Use}

\section{Context}

As the land use will change with the protein transition, the water use will also change because of the partial shift from cereals to soy. Ethiopia has a substantial amount of water resources but high hydrological variability, meaning that sometimes there is a lot of water available for different purposes and sometimes less. The surface water resource potential is significant, but little developed (yet). The internal renewable surface water resources are estimated at 120 billion $\mathrm{m}^{3} /$ year and renewable groundwater resources at around 20 billion $\mathrm{m}^{3} / \mathrm{year}$, but 18 billion $\mathrm{m}^{3}$ /year is overlap between surface water and groundwater, which gives a value of total internal renewable water resources (IRWR) of 122 billion $\mathrm{m}^{3} /$ year (FAO, 2016).

Agriculture is the main user of the available water. Based on the total irrigated area, cropping pattern and calendar, annual agricultural water withdrawal was estimated to be in the order of 5.2 billion $\mathrm{m} 3$ in 2002, while municipal and industrial water withdrawals were estimated to be about 330 and 20 million m3, respectively. The agricultural water withdrawal in 2016 is estimated at around 9 billion $\mathrm{m} 3$. This number, however, seems to be a low estimate considering both the large increase in irrigated areas and the changing pattern in irrigated crops. The huge livestock withdrawal an estimated 687 million $\mathrm{m} 3$ in 2010. Municipal water withdrawal is estimated at 810 million $\mathrm{m} 3$ in 2005 and industrial demand is estimated at 51 million m3 (FAO, 2016).

\section{Modelling}

\section{Internal land total evaporation}

For this indicator we calculated the domestic land evaporation (m3) of soy and cereals of the three scenarios (Table 2; Hermelink and Conijn, 2021). For each scenario, total (evapo)transpiration of 
cereal and soy production was calculated by multiplying the crop physical area in a cell with the (evapo)transpiration per unit area corresponding to that cell. The annual precipitation and evapotranspiration by cereals and soybean and irrigation demand are presented in the following tables 6 and figures 6 .

Reflecting on the model results, precipitation is projected to increase in the modelled future climate, which could partly explain the increased precipitation surplus. However, increased precipitation generally also leads to increased transpiration if water is limiting. In table 6 the results are graphically displayed of the annual difference of precipitation and evapotranspiration from cereals and soy ( $\mathrm{mm} / \mathrm{yr}$ ) in each scenario. For a current climate protein transition scenario, it shows that at more place in the country there is a deficit (more red areas). In the future it shows with a protein transition, the water availability increases.

For cereals and soy in Ethiopia, it is unclear whether water is a limiting factor, as the lower irrigated yields compared to the rainfed yields Error! Reference source not found.seem to indicate that $w$ ater is not limiting, while the precipitation deficits in Error! Reference source not found. seem to indicate the opposite. Transpiration is projected to decrease in the modelled future climate, despite increasing precipitation and temperature (Error! Reference source not found.). This c ould be explained by the shorter growing period of the cereals, which would cause less transpiration. However, the relative decrease in transpiration is much larger than the relative decrease in growth duration, which is still not well understood yet.

Evaporation is also projected to decrease, but it is still unclear why this is the case. A shorter growing season would be expected to lead to more evaporation outside of the growing season. Moreover, a higher temperature would also be expected to increase evaporation.

Table 6 For each scenario, the average annual evapotranspiration (ET), transpiration, and evaporation of cereals and soy, and the average annual precipitation $(P)$ and temperature on cells with cereals or soy. Averages are weighted for cell area of each crop. The difference between the annual ET and P (i.e. the rainfall deficit or surplus on cereals and soy) is indicated in the bottom row. Current and future situations were averaged over 1986 to 2016 and 2036 to 2065 respectively (Hermelink and Conijn, 2021)

\begin{tabular}{|c|c|c|c|}
\hline & $\begin{array}{l}\text { Scenario A: } \\
\text { Current climate }\end{array}$ & $\begin{array}{c}\text { Scenario B: } \\
\text { Current climate + } \\
\text { Protein shift }\end{array}$ & $\begin{array}{c}\text { Scenario C: } \\
\text { Future Climate + } \\
\text { Protein shift }\end{array}$ \\
\hline Average Temperature $\left({ }^{\circ} \mathrm{C}\right)$ & 19 & 19 & 21 \\
\hline $\begin{array}{l}\text { Annual Evapotranspiration } \\
(\mathrm{mm} / \mathrm{y})\end{array}$ & 1369 & 1386 & 1142 \\
\hline $\begin{array}{c}\text { Annual Transpiration } \\
(\mathrm{mm} / \mathrm{y})\end{array}$ & 580 & 590 & 418 \\
\hline $\begin{array}{c}\text { Annual Evaporation } \\
\qquad(\mathrm{mm} / \mathrm{y})\end{array}$ & 789 & 795 & 724 \\
\hline Annual Precipitation $(\mathrm{mm} / \mathrm{y})$ & 1172 & 1167 & 1226 \\
\hline Annual P - ET (mm/y) & -197 & -219 & 84 \\
\hline
\end{tabular}


Scenario A:

Current Climate

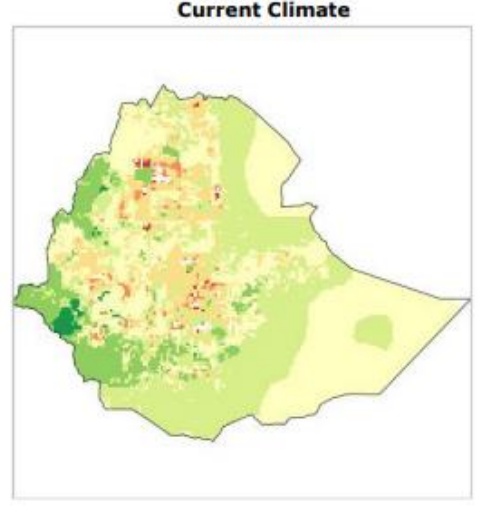

Scenario B:

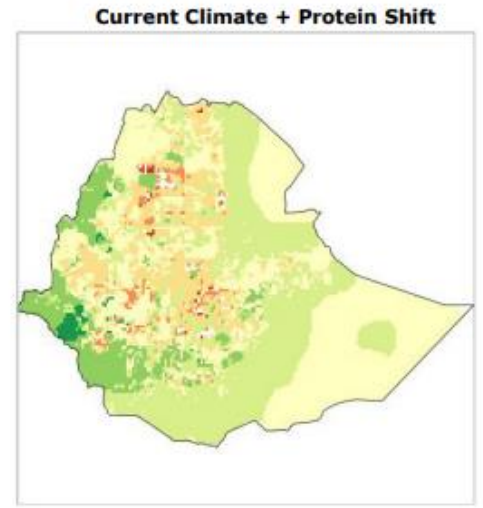

Scenario C:

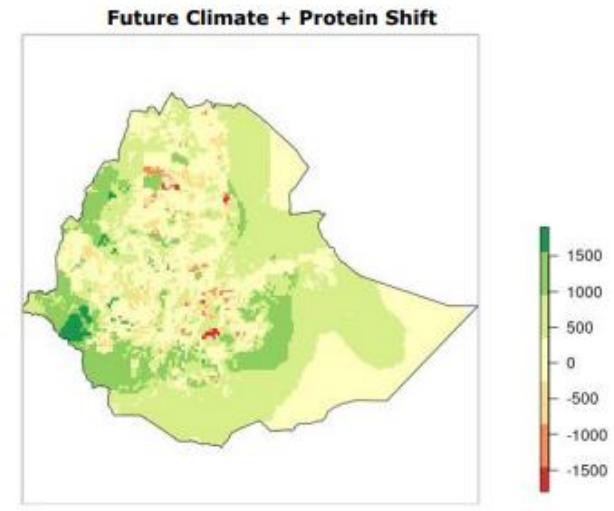

Figure 6 Difference between annual precipitation and evapotranspiration from cereals and soy $(\mathrm{mm} / \mathrm{yr})$ in each scenario. Current and future climate situations were averaged over 1986 to 2016 and 2036 to 2065 respectively (Hermelink and Conijn, 2021).

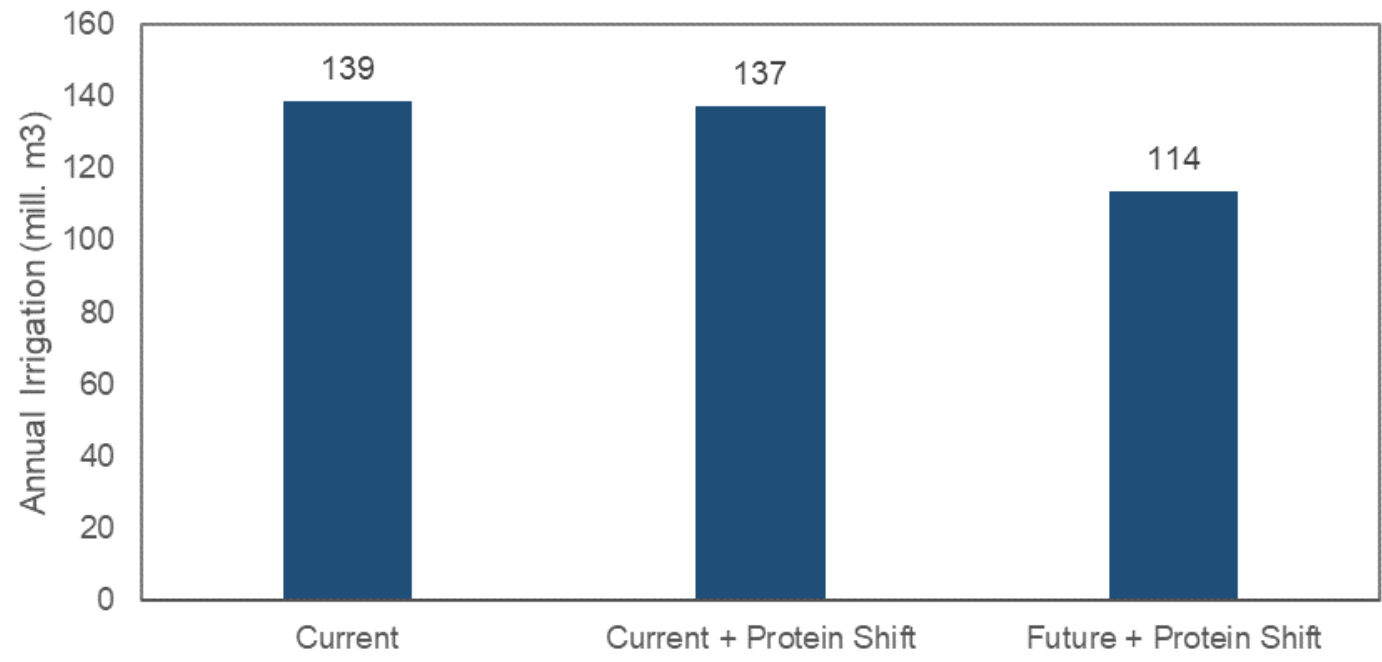

Figure 7 Average total annual irrigation volume for all CFTs across Ethiopia in each scenario. Averages were computed over 1986-2016 and 2036-2065 for the current and future climate respectively (Hermelink and Conijn, 2021).

As agriculture is the biggest water user, the modelled irrigation water use is also interesting to reflect on. It can be stated that there are very limited irrigated areas in Ethiopia, to the point that they can be considered negligible. Except for sugarcane, irrigated land area percentages range from 0 to $3.75 \%$ per crop, making irrigated agriculture irrelevant in the current agricultural production system in Ethiopia (Hermelink and Conijn, 2021). Figure 7 shows the outcomes of annual irrigation volumes for all scnearios. For the future irrigation water use, there will be a relatively small decline in water use. Overall, we can conclude that the dietary shift would not lead to major changes in water availability, and that compared to the current climate the transition would not suffer from higher rainfall deficits in the projected future climate; however, it is still necessary to further analyse model outcomes to better understand these results. 


\section{Other Indicators: Greenhouse Gas Emissions and Agriculture fertilizer use}

The greenhouse gas emissions and the nutrient losses are not modelled as time and expertise did not allow for in-depth modelling of these indicators. Instead, we used relatively simple calculations for a quick insight in possible impacts of the dietary shift. Greenhouse gas emission in Ethiopia is estimated at $150 \mathrm{Mt} \mathrm{CO2-eq.} \mathrm{and} \mathrm{represented} \mathrm{less} \mathrm{than} 0.3 \%$ of the global emissions in 2010 (Berhanu et al., 2019). Estimates of $\mathrm{CH} 4$ emission (data from the World Bank) indicate that agriculture, almost entirely through livestock, emitted 60.3 Mt CO2-eq. in 2008, which is approximately $71 \%$ of the national $\mathrm{CH} 4$ emissions (Berhanu et al., 2019).

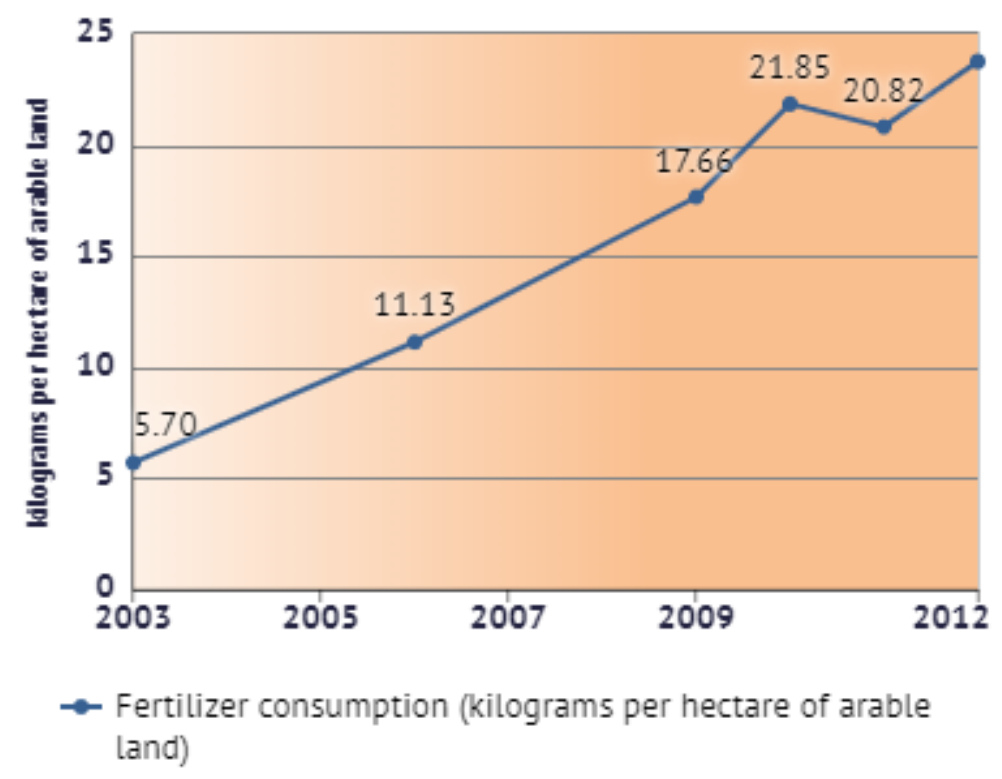

Figure 8 Evolution of fertilizer consumption (WDI, 2014)

Domestic greenhouse gasses (ton C02 equivalent)

In our approach only $\mathrm{N} 2 \mathrm{O}$ emissions are calculated (if $\mathrm{CO} 2$ and $\mathrm{CH} 4$ emissions linked to the cultivation of either cereals or soy are not different). We have followed the approach of the IPCC of calculating the $\mathrm{N} 20$ emissions. For this approach $\mathrm{N} 2 \mathrm{O}$ emissions mainly come from fertilizer use (1) (both (in)organic), crop residues left in the field (2) and possible land use change (3) (Chai et al.,2019). Next to this, we have assumed that for soy no nitrogen fertilizer is used as it is able to fix nitrogen from the atmosphere. We use a relatively simple approach to calculate these three factors. For the first one, we focus on the amount of land switched from wheat to soy and used an average fertilizer use per ha. Based on FAO data we can assume that the average fertilizer use per ha is $8.95 \mathrm{~kg} \mathrm{~N} /$ ha in 2017 in Ethiopia, and we used 298 as Global Warming Power (GWP) of $\mathrm{N} 20$ ( $\mathrm{g} \mathrm{CO} 2 \mathrm{eq} / \mathrm{g} \mathrm{N} 2 \mathrm{O}$ ). For the second source we use the amount of area (numbers origin from section land-use changes Ethiopia and average fertilizer use. We use the new land use scenarios (matching with the protein transition scenarios) and thus new crop areas, to calculate the new fertilizer use. The last source is calculated following the FCR approach presented in Annex 7. Outcomes are presented in table 8, table 9 and table 10. 
Calculations land use

For the land use changes, the change from cereals to soy are interpreted as moving from cropland to cropland. Therefore, for this calculation only the amount of land is considered between the scenarios.

Table 7 Overview land use calculations

\begin{tabular}{|l|l|l|l|l|}
\hline & Scenario A & Unit & $\begin{array}{l}\text { Scenario } \\
\text { B+C }\end{array}$ & unit \\
\hline Total cropland area (cereals+ soy) & 10396339.1 & ha & 9858834.8 & ha \\
\hline
\end{tabular}

Calculation's fertilizer use

For the agricultural fertilizer use, we have used also the land use changes and multiplied this with average fertilizer use (as presented earlier, we are assuming that soy does not need fertilizer). The fertilizer use is presented in table 8 . It shows that there is a decrease in fertilizer use, which is expected as less cereals are harvested in scenario $\mathrm{B}+\mathrm{C}$.

Table 8 Over Agricultural fertilizer use calculations

\begin{tabular}{|l|l|l|l|l|} 
& Scenario A & Unit & $\begin{array}{l}\text { Scenario } \\
\text { B+C }\end{array}$ & unit \\
\hline area & 10353600 & $\mathrm{ha}$ & 9598400 & $\mathrm{ha}$ \\
\hline fertilizer use & 36.2 & $\mathrm{~kg} / \mathrm{ha}$ & 36.2 & $\mathrm{~kg} / \mathrm{ha}$ \\
\hline fertilizer use cereals & 374800320 & $\mathrm{~kg} \mathrm{~N}$ & 347462080 & $\mathrm{~kg} \mathrm{~N}$ \\
\hline
\end{tabular}

Calculations crop residues

The crop residues calculations are shown in Annex 8. The FCR is calculated for both soy and cereals.

Table 9 overview crop residues calculations

\begin{tabular}{|l|l|l|l|l|}
\hline & Scenario A & Unit & $\begin{array}{l}\text { Scenario } \\
\text { B+C }\end{array}$ & Unit \\
\hline FCR cereals & 281398 & $\mathrm{~kg} \mathrm{~N} / \mathrm{y}$ & 260873 & $\mathrm{~kg} \mathrm{~N} / \mathrm{y}$ \\
\hline FCR soy & 1924 & $\mathrm{~kg} \mathrm{~N} / \mathrm{y}$ & $11726 \mathrm{~kg} \mathrm{~N} / \mathrm{y}$ \\
\hline
\end{tabular}

Overview

Putting the results of Land use changes, fertilizer use changes and crop residues changes together, the following results are presented in table 10. This shows that the amount of $\mathrm{C} 02$ equivalent decreases in scenarios $B$ and $C$.

Table 10 Summarized calculations

\begin{tabular}{|l|l|l|l|l|}
\hline & Scenario A & Unit & $\begin{array}{l}\text { Scenario } \\
\text { B+C }\end{array}$ & Unit \\
\hline N20-N inputs & 3750817.184 & N2O-N yr-1 & 37508.17184 & N2O-N yr-1 \\
\hline N20-NOS & 51981695.65 & $\mathrm{~kg} \mathrm{N2O}-\mathrm{N}$ yr-1 & 49294173.91 & $\mathrm{~kg} \mathrm{N2O-N} \mathrm{yr-1}$ \\
\hline N O N 2 Direct & 55732512.84 & $\mathrm{~kg} \mathrm{~N} 2 \mathrm{O}-\mathrm{N}$ yr-1 & 49331682.08 & $\mathrm{~kg} \mathrm{N2O-N} \mathrm{yr-1}$ \\
\hline N20 & 87579663.03 & $\mathrm{~kg} \mathrm{N2O}$ yr-1 & 77521214.7 & $\mathrm{~kg} \mathrm{N2O} \mathrm{yr-1}$ \\
\hline & 86196.78 & tons N20 yr-1 & 76297.154 & tons N20 yr-1 \\
\hline N20 - CO2 equivalents & 25686640.48 & C02 equivalent & 22736552.11 & C02 equivalent \\
\hline
\end{tabular}


Showing that the difference could lead up to $-29.5^{*} 10^{5} \mathrm{CO}^{2}$ equivalent increase from Scenario A to Scenario $B$ and $C$. This is a relatively big decrease (of around $11 \%$ ) and does not seem in line with expectations. A decrease was expected due to the decrease in fertilizer use and decrease of crop land area. One of the reasons the expectations defer from the outcomes, is that in these calculations, many assumptions have been made (average fertilizer use, FCR calculations, factors for land use changes etc.). The most impactful assumptions are the assumptions for cropland types in certain climates, assuming generic grain values, not including the net annual amount of $\mathrm{N}$ mineralised in mineral soils because of loss of soil carbon through change in land use or management. These assumptions require follow up research. 


\section{Case The Netherlands}

\subsection{Introduction Case The Netherlands}

In the same way as the case of Ethiopia, the Netherlands case follow the same structure. To guide the research, specific research questions are formulated for this case. First the specific research questions are presented and afterwards a short introduction into the context of the diet and soy in Netherlands.

\section{Specific research questions:}

- How would a $10 \%$ transition of protein affect dietary energy and fat intake?

- How would a $10 \%$ transition of protein source from cereals to soybean affect land use in Netherlands?

- How would the water balances (precipitation deficit/surplus and irrigation) be affected by the $10 \%$ transition in protein source with or without projected climate change?

- How would the greenhouse gas emission change by the protein transition?

- How much fertilizer use would change by the protein transition?

\section{Context case}

The Netherlands has a relatively high intake of animal protein as described in the introduction. In general, production of animal protein has a higher impact on the environment compared to plantbased proteins (Reijnders and Soret, 2003). In addition to the environmental impact, conscious food consumption patterns are growing in the Netherlands. Plant protein are seen as a healthier option compared to animal-based protein. This is not only linked to the protein component but mainly linked to fat intakes. Animal fats (including milk-based products) have a much higher content of saturated fats which pose a significant health risk (Aiking and de Boer, 2020). As a result, the demand for milk is reducing and there is an increased demand for alternatives such as soy drinks. These plant-based alternatives have a lower impact on the environment, but the question remains what the consequences can be of a transition to an alternative protein source on both diet and environment? As various soy products were one of the first alternatives in the market for animal proteins, we have chosen soy drink produced from Dutch soybean production as a case study. However, the methodology in this analysis can also be used for calculating the impact of other alternatives. For this protein transition we investigated the consequences of replacing $10 \%$ of the current protein intake with milk products by protein intake from soy drink on a number of selected indicators.

\section{Context current diet}

The average Dutch person drinks and eats $3 \mathrm{~kg}$ of food and beverages per day with on average $78 \mathrm{~g}$ protein/day (Rijksinstituut voor Volksgezondheid en Milieu Ministerie van Volksgezondheid, Welzijn en Sport, 2016). For legumes (such as beans and peas) the average consumption is 5 $\mathrm{g} /$ day, which is consumed once in every 3 weeks. In the Netherlands, the average person eats sufficient amounts of protein, unsatured fat and carbohydrates (Rijksinstituut voor Volksgezondheid en Milieu Ministerie van Volksgezondheid, Welzijn en Sport, 2016). However, too much saturated fats are being consumed. The last years the Dutch population has been consuming less meat and dairy products. On average, around 100 grams of meat and 350 grams of dairy products are consumed per capita per day. That is respectively $8 \%$ and $12 \%$ less than in the years of 2007-2010. The lower consumption of red and processed meats could be beneficial for the overall health of the population with respect to chronic diseases. The consumption of dairy products does not need to decline any further with respect to calcium requirements and bone health (Rijksinstituut voor Volksgezondheid en Milieu Ministerie van Volksgezondheid, Welzijn en Sport, 2016). 


\section{Context soy}

In the Netherlands it is possible to grow and harvest soy with varieties adapted to the North-west European climate. In the 1930s, there was already production of soy in the Netherlands, however this was not very successful. After those years, some initiatives have been implemented but it always stayed in the experimenting phase. Until recently there were some developments towards more adjusted varieties. This is referred to as "Nedersoja". In this research we focus on the Nedersoja and not imported soy (Timmer, n.d.).

Most of the human consumption of soy in the Netherlands is indirectly using soy in animal feed, whereas only a small part of the soy in the Netherlands is consumed directly as soy drink and tofu (Achtergrondrapport Sojabarometer 2012; LEI, 2006)(CBS, 2014).

\subsection{Approach Case The Netherlands}

Also, for the Netherlands an approach is followed based on the same approach as the case in Ethiopia. This includes indicators presentation in table 7 and elaboration of the indicators and data sources in table 8 and 9. Afterwards a more in-depth explanation of the WOFOST model is presented and the use of the model for this case.

\section{Table 11 Indicators for environment and health in The Netherlands (at national level)}

\section{Indicators}

- Land use food \& feed production (ha)

- Agricultural total evaporation and runoff (m3)

- Agricultural greenhouse gass emission (ton C02 equivalent)

- Agricultural fertilizer use (ton N)

- Dietary energy intake (kcal)

- Nitrogen losses (kg nitrate \& kg ammonia)

\section{Table 12 Overview indicators Netherlands}

\begin{tabular}{|c|c|c|c|}
\hline Scenario: & Baseline & 10\% Current & $10 \%$ Future \\
\hline & $\begin{array}{l}\text { Current diet, } \\
\text { Current climate, } \\
\text { year }=2015\end{array}$ & $\begin{array}{l}10 \% \text { protein transition, } \\
\text { current climate }\end{array}$ & $\begin{array}{l}10 \% \text { protein } \\
\text { transition, future } \\
\text { climate }\end{array}$ \\
\hline Diet & \multicolumn{2}{|l|}{ Health aspects } & $\begin{array}{l}\text { (same diet as in } 10 \% \\
\text { Current) }\end{array}$ \\
\hline Production & \multicolumn{3}{|c|}{ Yield and total production of grass and feed crops } \\
\hline Land use & \multicolumn{2}{|c|}{ Harvested areas of grass and feed crops } & $\begin{array}{l}\text { (same as in } 10 \% \\
\text { current) }\end{array}$ \\
\hline Water use & (not determined) & \multicolumn{2}{|c|}{ EvapoTranspiration \& irrigation } \\
\hline $\begin{array}{l}\text { GHG } \\
\text { emissions }\end{array}$ & \multicolumn{2}{|l|}{ GHG footprint } & $\begin{array}{l}\text { (same as in } 10 \% \\
\text { current) }\end{array}$ \\
\hline $\begin{array}{l}\text { Nutrient } \\
\text { losses }\end{array}$ & \multicolumn{2}{|l|}{ NH3 footprint } & $\begin{array}{l}\text { (same as in } 10 \% \\
\text { current) }\end{array}$ \\
\hline
\end{tabular}

Table 13 Data sources indicators Netherlands 


\begin{tabular}{|c|c|c|c|}
\hline & $\begin{array}{l}\text { Current diet, } \\
\text { Current climate, } \\
\text { year }=2015\end{array}$ & $\begin{array}{l}10 \% \text { protein transition, } \\
\text { current climate }\end{array}$ & $\begin{array}{l}10 \% \text { protein transition, } \\
\text { future climate }\end{array}$ \\
\hline Diet & \multicolumn{2}{|c|}{ Food Balance Sheets of FAO, NEVO } & $\begin{array}{l}\text { (same diet as in } 10 \% \\
\text { Current) }\end{array}$ \\
\hline Production & CBS & CBS, WOFOST & WOFOST \\
\hline Land use & (StatLine) & & $\begin{array}{l}\text { (same as in } 10 \% \\
\text { current) }\end{array}$ \\
\hline Water use & (not determined) & WOFOST & \\
\hline GHG emissions & \multicolumn{2}{|c|}{ Literature (NZO, others) } & $\begin{array}{l}\text { (same as in } 10 \% \\
\text { current) }\end{array}$ \\
\hline Nutrient losses & \multicolumn{2}{|c|}{ Literature (CBS, others) } & $\begin{array}{l}\text { (same as in } 10 \% \\
\text { current) }\end{array}$ \\
\hline
\end{tabular}

WOFOST and use of the model

We used the WOFOST model in combination with various data sets from FAO, CBS, and NZO to study the consequences of replacing $10 \%$ of the current protein intake with milk products by protein intake from soy drink on a number of selected indicators: diet, production, land use, water use, GHG emissions, and Nutrient loss (Figure 9 ).

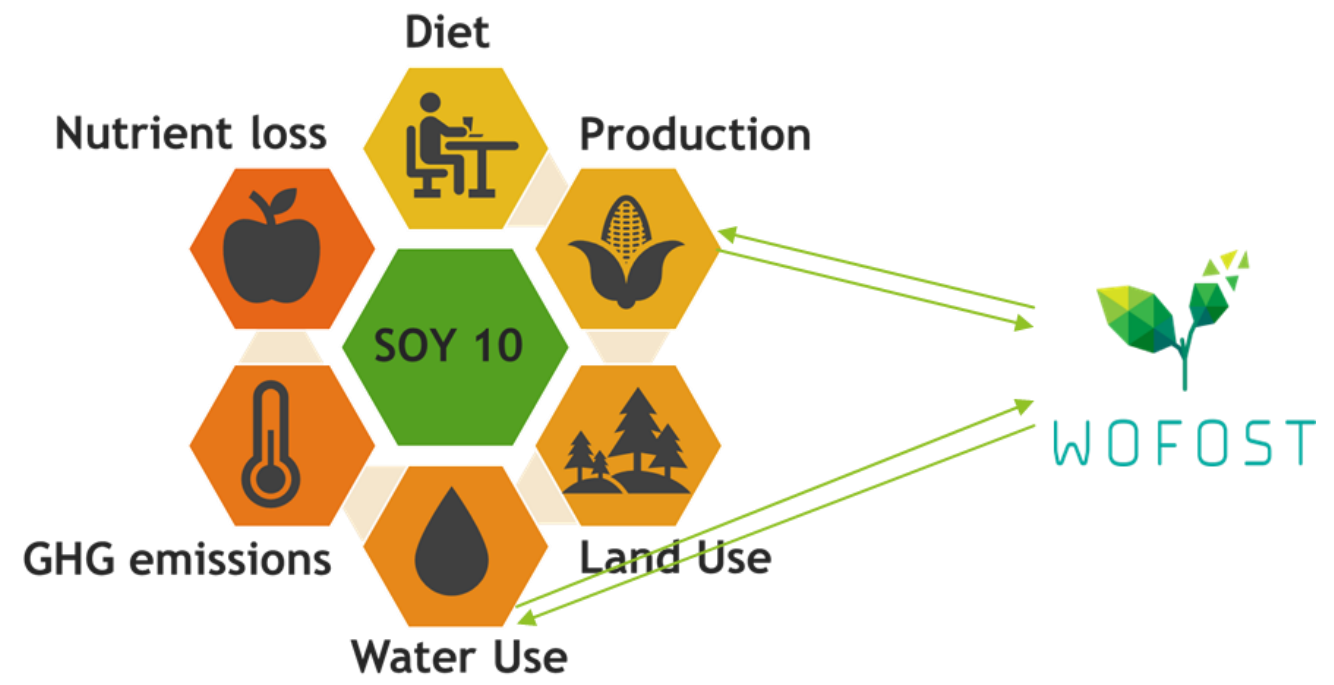

Figure 9: A pictorial representation of the core of the study and the role of the crop modelling approach.

We analysed the impacts of the protein transition for the current and a possible future climate situation. To estimate the impacts of protein transition in the future climate, we have used the crop modelling approach for various agronomic scenarios (Irrigated and Rainfed). The technical report thoroughly discusses the modelling approach and its role in the protein transition study mainly focused on the production and water use (Ara, 2021).

WOFOST can be used to simulate different levels of the yields (potential, water-limited, and actual). Here, we used the model to simulate crop yields at water-limited and potential levels. The hierarchy of the model simulation is shown in figure 10 . To estimate the impacts of the protein transition, we have simulated a major cereal (wheat) and two fodder crops (silage maize, grassland), which contribute indirectly to milk protein production. 


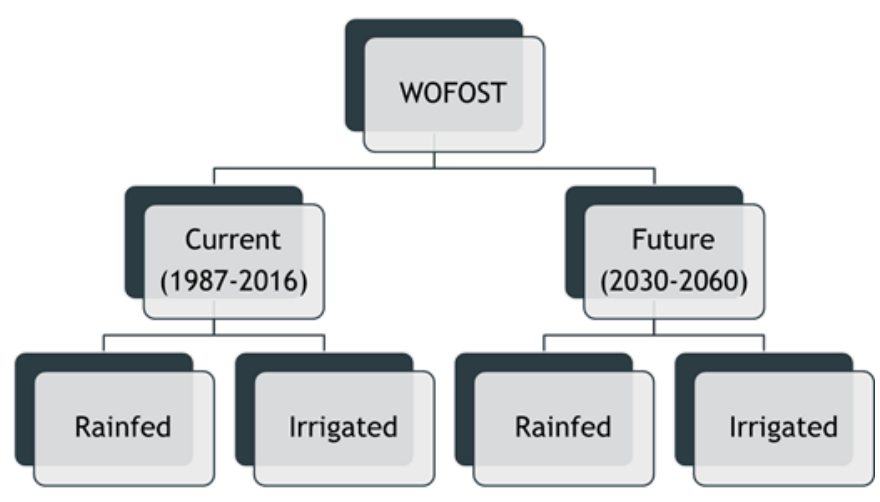

Figure 10: WOFOST model simulation hierarchy

\subsection{Water-Limited Production}

The water-limited production is determined by the water availability as well as water use during the growth of the crop. Water use is mainly determined by crop transpiration and soil evaporation. The initial water availability determines the crop water requirement during the crop growth period, the maximum soil water holding capacity dependent on rooting depth and the available soil moisture fraction, and the balance of water inputs (mainly precipitation) and use during the growth period. The initial soil water availability in the maximum rooting depth should be based on the measurement of soil moisture content at crop emergence or should be based on the water balance calculation during the months before crop emergence. Often only a rough estimate for the initial soil water availability is available for the WOFOST simulation. However, the sensitivity of waterlimited production to this initial soil water availability is often quite substantial. The maximum soil water holding capacity is determined by the maximum rooting depth (of a full-grown crop) and the available soil moisture fraction (moisture content at field capacity minus that at the permanent wilting point). For these three variables, reliable values are available for each soil type for which WOFOST simulations are done to achieve precise water-limited crop production analyses.

\subsection{Potential Production}

Crop growth is determined only by $\mathrm{CO} 2$ concentration, irradiation, temperature, plant characteristics, and planting date. Potential production represents the absolute production ceiling for a given crop variety when grown in each area under specific weather conditions. It is determined by the crop's response to the temperature and solar radiation regimes during the growing season. Atmospheric $\mathrm{CO} 2$ concentration is assumed to be constant. All other factors are assumed to be optimal (e.g., pest and weed control, no losses caused by traffic or grazing) and in ample supply (nutrients and water). Because crop properties also determine potential yield, yield potential varies over crop varieties and can be increased by breeding. Near to potential yield, levels are realized in field experiments by research institutes, seed companies, and some frontrunner farmers. 


\section{Diet Netherlands}

For the diet (change) and its relationship with production, data on milk products and soybeans from the Food Balance Sheet (FBS) of the FAO for The Netherlands in 2015 have been used in this project. According to the FBS, both the production and food supply of soybeans was either zero or negligible in 2015. Although small amounts of soybeans are directly consumed by the Dutch population, large amounts of soybeans are imported, exported, and processed for feed and vegetable oil for human use (Annex 5, Table 5.1). Protein intake with milk products was estimated by the food protein supply of milk products from the FBS and the relative food loss estimations in household and retail for Europe (Gustavsson et al., 2011). This food loss estimate for milk products has also been used for soy drink. In the protein transition scenario, the protein intake of milk products is assumed to be reduced with $10 \%$ and this reduction in intake is replaced by the same absolute protein amount from soy drink. This amounts to a reduction of $3.1 \mathrm{~g} / \mathrm{capita} / \mathrm{day}$ of milk protein supply (from 30.7 to $27.6 \mathrm{~g} / / \mathrm{cap} / \mathrm{d}$ ) and an identical increase in soy drink protein supply (Annex 5, Table 5.1). The protein supply by soybeans increases from practically zero to 3.1 $\mathrm{g} / \mathrm{cap} / \mathrm{d}$, because soy oil, produced from imported soybeans and consumed in significant amounts, does not contain protein (according to the food composition table of the FAO).

Based on the FBS, the change in protein intake (less from milk, more from soy drink) leads to both a lower fat intake (-0.9 g/capita/day) and a lower food energy intake (-43 kcal/capita/day) in the protein transition scenario compared to the current situation.

The Dutch Food Centre ("Voedingscentrum") gives information on the use of soy drink as replacement of milk. In principle soy drink can be part of a healthy diet if it fulfils several recommendations and then it can contribute to lowering the LDL cholesterol levels which prevent cardiovascular diseases. Pregnant women should be careful not to consume too much soy drink, due to the isoflavones which may affect the development of the child. Because natural soy drink has no vitamin B12 and a low calcium content compared to milk, the Dutch Food Centre advises to use soy drink types that have been fortified with additions of vitamin B12 and calcium, such as the example in the last column of Table 1. Recommendations have also been mentioned for protein, sugar and saturated fat, and these are well satisfied by both soy drink types. Contrary to milk, soy drink contains small amounts of iron and its consumption can therefore contribute to the recommended daily intake of circa $13 \mathrm{mg}$ iron per day. On the other hand, soy drinks contain no iodine, whereas milk consumption can be important for reaching sufficient iodine intake levels. When milk is replaced by soy drink, more iodine may have to be obtained via an increase in the consumption of e.g., bread, fish, and eggs. 
Table 14 Comparison of milk and two types of soy drink with recommendations ${ }^{2}$

\begin{tabular}{|c|c|c|c|}
\hline Recommendations & $\begin{array}{r}\text { Milk, } \\
\text { semi- } \\
\text { skimme } \\
\text { d }\end{array}$ & Soy drink, natural & Soy drink, Original Alpro \\
\hline$>1.4 \mathrm{~g} / 100 \mathrm{ml}$ & 3.4 & 3.4 & 3.0 \\
\hline$>0.24 \mu \mathrm{g} / 100 \mathrm{ml}$ & 0.45 & 0 & 0.38 \\
\hline$>80 \mathrm{mg} / 100 \mathrm{ml}$ & 123 & 12 & 120 \\
\hline$<6 \mathrm{~g} / 100 \mathrm{ml}$ & 4.7 & 1.4 & 2.4 \\
\hline$<1.1 \mathrm{~g} / 100 \mathrm{ml}$ & 0.9 & 0.3 & 0.3 \\
\hline$>150 \mu \mathrm{g} / \mathrm{d}$ & 14.9 & 0 & 0 \\
\hline$>13 \mathrm{mg} / \mathrm{d}$ & 0 & 0.3 & 0.4 \\
\hline
\end{tabular}

\footnotetext{
${ }^{2}$ Recommendations per $100 \mathrm{ml}$ have been obtained from the Dutch Food Centre (https://www.voedingscentrum.nl/nl.aspx) and those for iodine and iron (per day) from the Health Council of the Netherlands ("Gezondsheidsraad"; https://www.gezondheidsraad.nl/). Content values of the three food drinks have been obtained from the online NEVO database (NEVO (rivm.nl); expressed per $100 \mathrm{~g}$ ).
} 


\section{Modelling Netherlands}

\subsection{Land Use}

Context

The Netherlands is still a green country; almost $80 \%$ of the surface is in use for recreation, agriculture, forest and nature. The rest of the $15 \%$ is "red space" (infrastructure, living, building and other build structures). The agriculture sector is the biggest land user. Around $66 \%$ of the land is used by agriculture. The land-use is visually displayed in figure 11 (CBS, 2015).

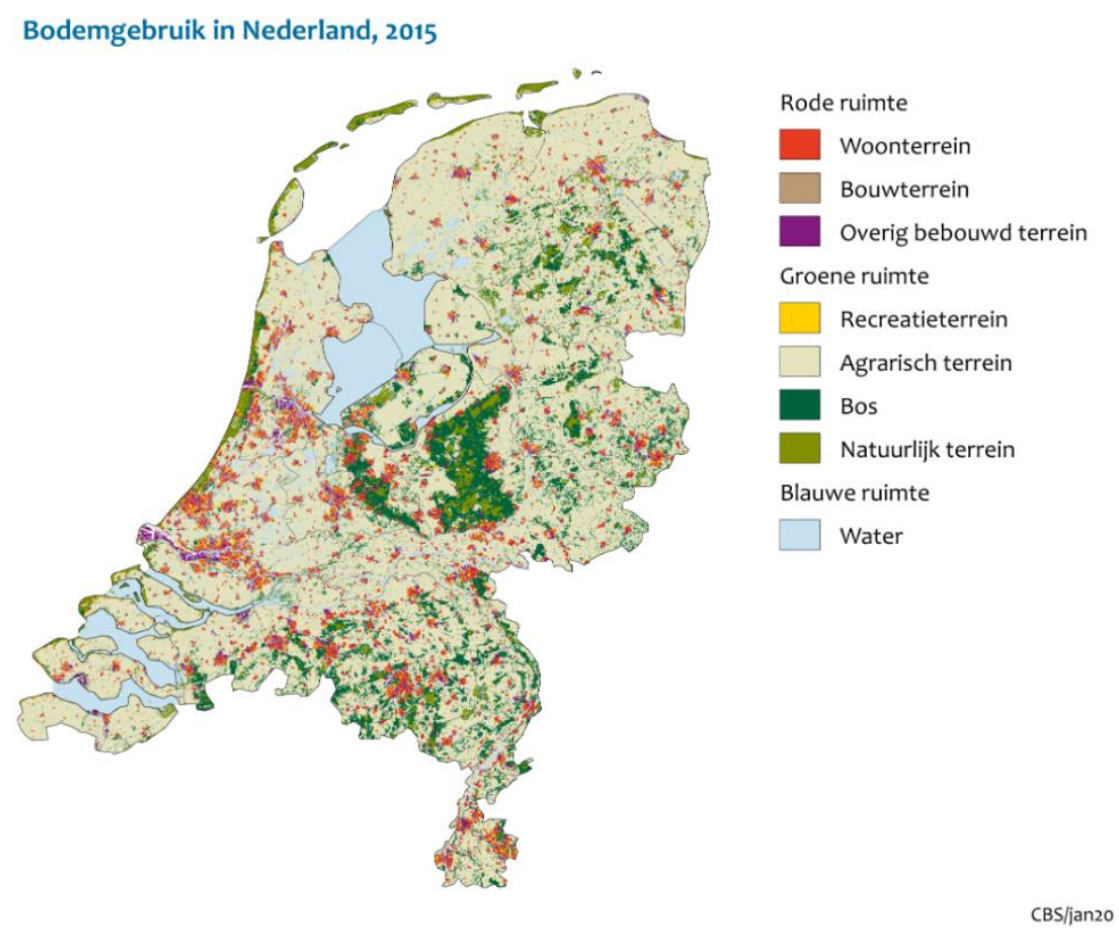

Figure 11 Map Land use of Netherlands 2015 (CBS, 2015)

\section{Modelling}

Using the methodology of the FBS, differences in the production of milk was calculated as follows. The food supply of milk products, in 1000 tonnes per year, was found by applying the ratio between food and protein supplies (as apparent in the data from the FBS) to the new milk product protein supply in the protein transition scenario. According to the FBS, no loss occurred in 2015 during storage and transportation of milk products. All categories, except food, were kept identical to the FBS data of 2015 (Annex 5, Table 5.1). In the protein transition scenario, the production of milk is reduced with almost 500 ktonnes per year $(-3.8 \%)$. This is much lower than the $10 \%$ change in the consumption of milk products, because a large part of the milk products produced in the Netherlands is exported. For soybeans a different approach has been used. The additional soybean production was calculated by combining the additional soy drink in the protein transition scenario with (a) the ratio of protein concentrations in soy drink and soybean and (b) the share of soybean protein that goes into the soy drink. For this share a value of 0.83 was estimated, where the remaining part is used for the production of animal feed (not all protein of the beans ends up in the drink). The concentration ratio has approximately a value of 0.1 , reflecting the addition of water (10:1) during the production of soy drink from soybeans (Annex 6, Table 6.1). An additional soybean production of 60.3 ktonnes /year was calculated for the supply of soy drink in the protein transition scenario (Annex 5, Table 5.1). 
Land use changes in the protein transition scenario relative to the original situation in 2015 were estimated as function of the production differences of milk ( -515 ktonnes) and soybean ( +60.3 ktonnes). For soybean an average yield in The Netherlands in 2015 of $3000 \mathrm{~kg} / \mathrm{ha}$ was applied (Verstand et al., 2020), which results in an additional required area for soybean of 20.1 kha. The harvested soybeans are used to produce soy drink, but also yields an amount of animal feed. It is assumed that this feed replaces imported soy feed from South America. It may have consequences for land use in South America, but not in the Netherlands. On the other hand, this assumption affects the estimated GHG emissions in our calculations. For the lower milk production less roughages are needed, and this was estimated by using their feed conversion ratios ( $\mathrm{g}$ feed dry matter per g milk) and dry matter (DM) yields for grass and silage maize in 2015 (Annex 6, Table 6.1). Milking cows also eat concentrates and by-products (estimated at $30 \%$ on a DM basis, where the roughages contribute $70 \%$ to the total ration for producing milk). Part of this $30 \%$ contains main crop products (like wheat) while the other part consists of residues (such as from the food industry). It is assumed that $75 \%$ of the dry matter intake from concentrates and by-products that are no longer needed in the protein transition scenario, will replace crops grown for feed in the Netherlands. For the calculation of the amount of land that is involved, we used the yield of wheat in 2015 as a proxy for these crops. Combining the lower milk production of 515 ktonnes with the parameters for grass, silage maize and wheat gives areas no longer needed of $15.8 \mathrm{kha}$ silage maize and wheat, and 21.1 kha grassland. Net values amount to a required area for crop land of 4.3 kha (area of soy minus areas of silage maize and wheat) and an area of 20.1 kha of grassland no longer needed. These results are displayed in figure 12 and figure 13. Overall, less land is needed in the protein transition scenario (16.8 kha), but some of the original grassland will be required as cropland in this scenario and this may have unwanted consequences for soil carbon sequestration.

Producing milk also produces meat, e.g., from slaughtered mature milking cows. Lower milk production could therefore affect meat production. However, in this project we have not taken this into account, because the milk production is only reduced by $3.8 \%$, and it is assumed that this will affect the milk production per cow rather than the number of cows.

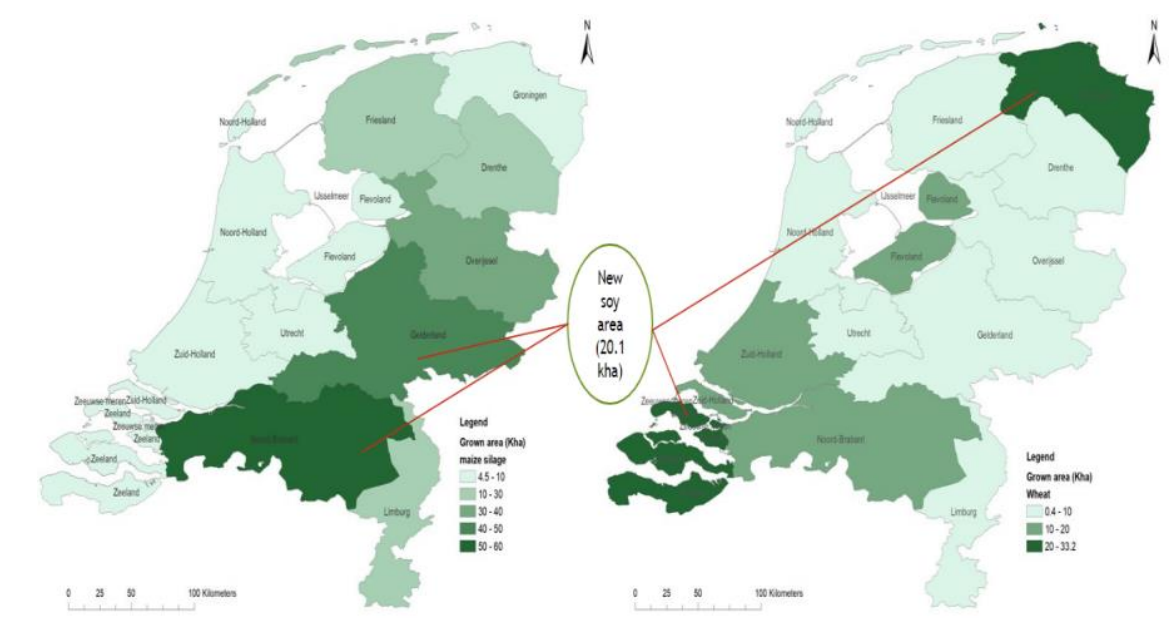

Figure 12 Grown area of Wheat and Maize silage in 2015 (Arumugam, 2021) 


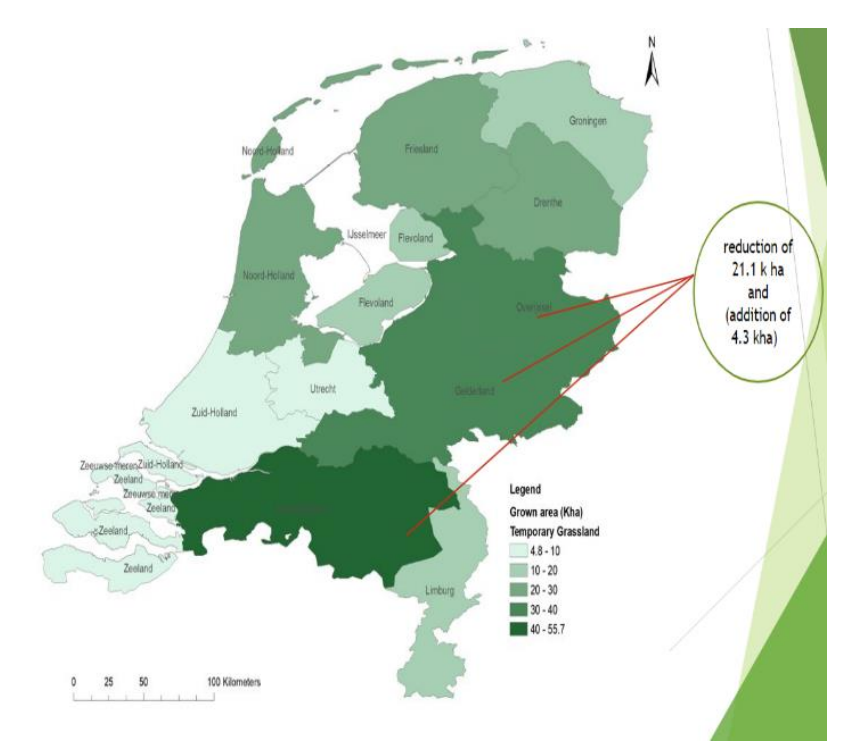

Figure 13 Grown area of Temporary Grassland in 2015

\subsection{Water Use}

\section{Context}

Over $50 \%$ of productive agricultural land in the Netherlands is grassland dedicated to supporting the dairy industry. There are more than 100 types of grass species grown in the Netherlands. However, in recent times, to optimize yield, farmers have started growing only a single type of highly productive grass (monoculture) at the expense of less productive but more herbaceous grassland (Ellipsis Drive, 2021). An increase in temperature and CO2 concentration in the air has a favourable effect on grassland production in the Netherlands. However, this favourable effect is (partly) undone by the increased probability of a water shortage (due to a reduction in rainfall) in the summer (Schipper et al., 2014) (Arumugam, 2021)

\section{Modelling}

For grassland we calculated an overall $10 \%$ decrease in yields and a $3 \%$ decrease in water use efficiency from the scenario B current to scenario $C$. The total water use however is reduced by $13 \%$ from $431 \mathrm{~mm}$ to $377 \mathrm{~mm}$ per year (Polley et al., 1997), mainly due the impact of higher atmospheric $\mathrm{CO} 2$ atmospheric concentrations which reduces transpiration.

For silage maize (Zea mays L.) yields under the future climate are simulated to slightly decrease from 12.3 to $11.8 \mathrm{t}$ dry matter/ha. At the same time, higher water use and water use efficiency have been calculated in both irrigated and rainfed levels. Water Use is projected to increase slightly from $335 \mathrm{~mm}$ to $345 \mathrm{~mm}$ during the crop growth period (Tao and Zhang, 2011). Water use of wheat is decreasing by almost $10 \%$ from $\sim 328 \mathrm{~mm}$ to $\sim 303 \mathrm{~mm}$ per year. Also, the yield of wheat is projected to slightly decrease.

The WOFOST model has simulated soybean yields under the current and future climate. The potential yield for soy will be between 3.5 and 4 t/ha in The Netherlands. Higher temperatures improve soybean cultivation as frost days are critical for soybean crop growth. Simulation results however show a slight decrease in potential yield. Decreased potential yields and minimal role of water can be explained by the processes of soil evaporation, interception losses, deep percolation, and surface runoff due to a combination of rainfall and irrigation (Rockstrom, 2000). The overall water use of soy is relatively high with $390 \mathrm{~mm} / \mathrm{ha} / \mathrm{yr}$ for the current situation. This slightly reduces 
under the future climate, but due to low yields soy has the lowest water use efficiency and uses 2 to 3 times more water for each ton of yield compared to maize and wheat. Grassland, wheat, and soybean use less water per ha to produce one ton of their productivity than the current in the future (Arumugam, 2021). In the process of protein transition, soybean's water use efficiency (less water required to produce one ton of soybean than the current in the future) is projected to be the higher and positive response of increasing temperature. Therefore, we conclude that soybean cultivation for protein shift is recommendable based on its water use efficiency.
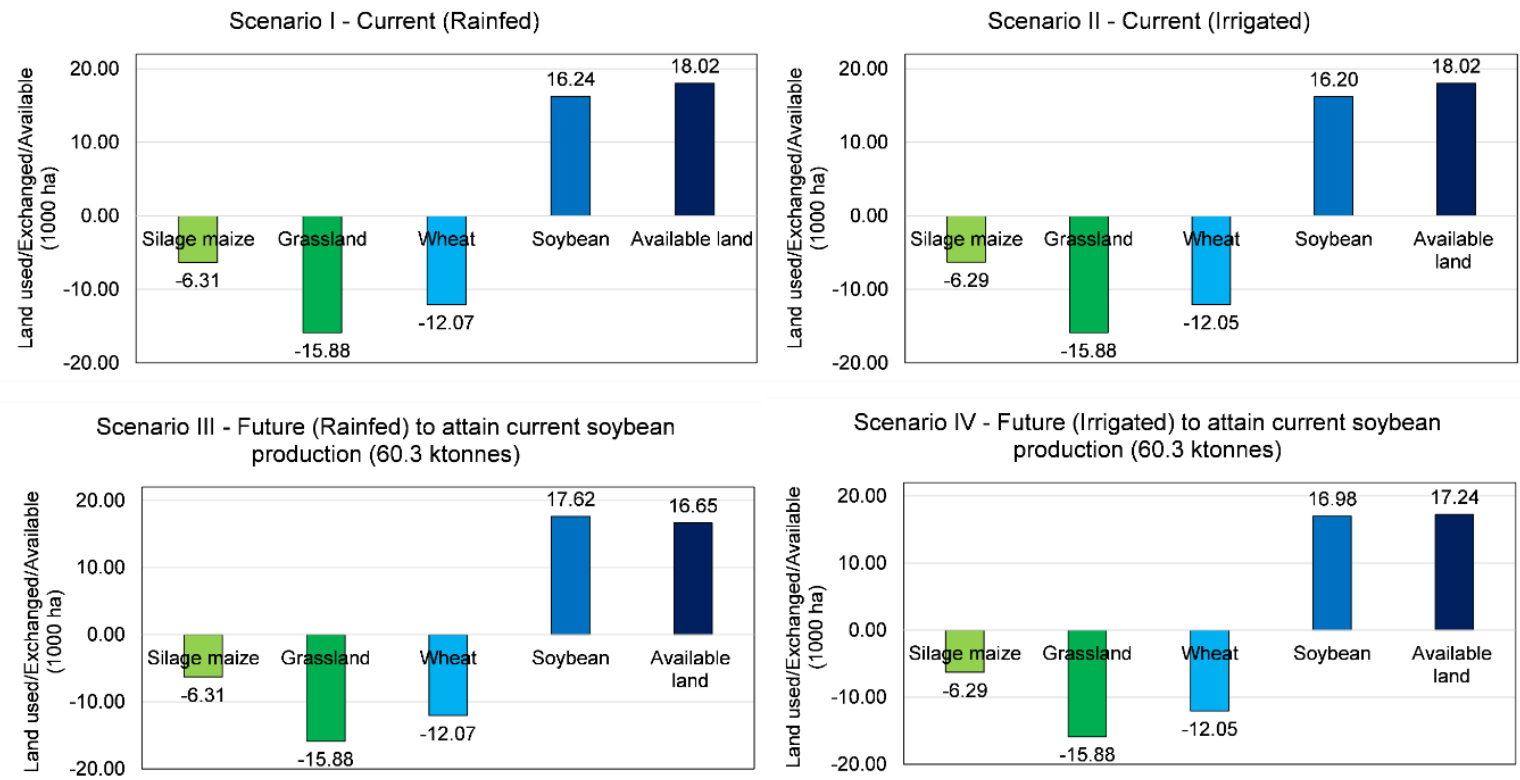

Scenario IV - Future (Irrigated) to attain current soybean production (60.3 ktonnes)

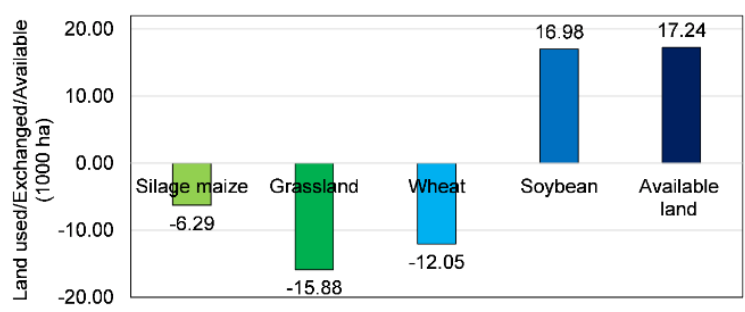

Figure 14 Overview of cultivation scenarios (Arumugam, 2021)

Compared to Scenario I and Scenario III (Current rainfed Vs. Future Rainfed), their land availability is reduced from 18002 ha to 16650 ha, and almost 1500 ha, additionally needed for soybean cultivation. Vice versa Scenario II and Scenarios IV (Current irrigated Vs. Future Irrigated), their land availability is reduced from 18002 ha to 17240 ha, and almost 800 ha, additionally needed for soybean cultivation. Comparing irrigation and rainfed scenarios in the future, irrigated scenario needs less land (640 ha) to produce 60.3 ktonnes (need for $10 \%$ protein transition) than rainfed as the water use efficiency of soybean is projected to increase. Overall, both irrigated and rainfed soybean can free land from 16650 ha to 17240 ha, in the process of $10 \%$ soy transition (Arumugam, 2021) 
Soybean (Yield)

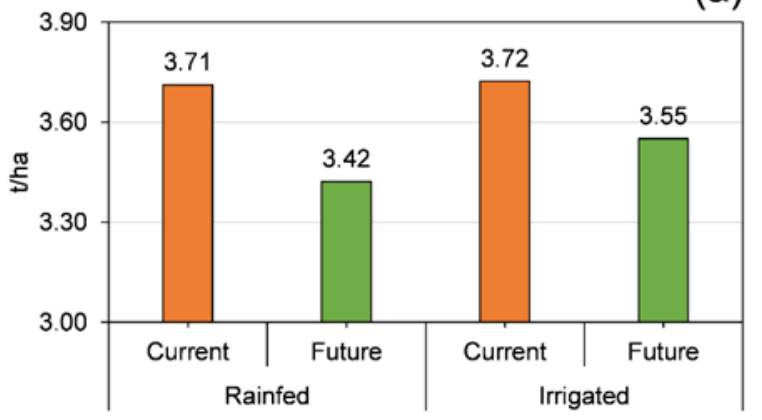

(a)

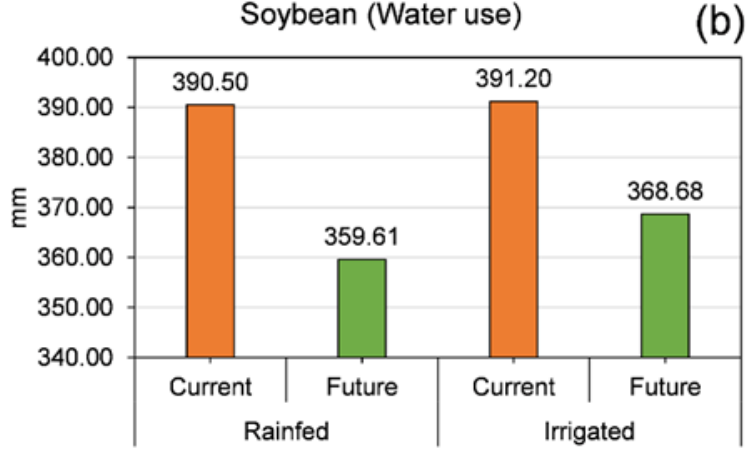

(c)

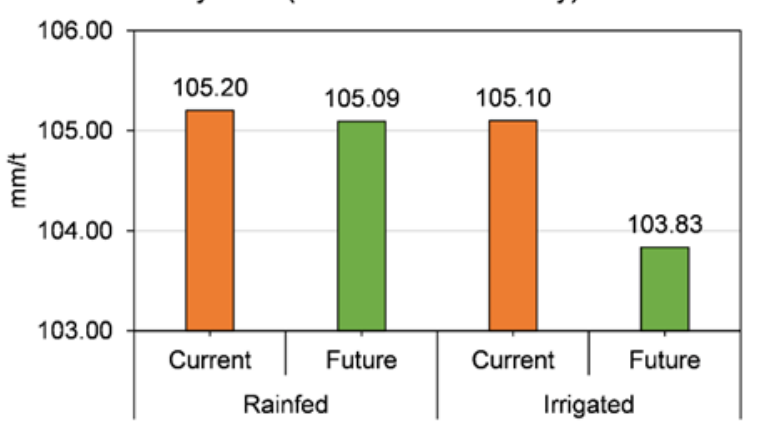

Figure 15: a) Simulated yields, b) water use (evapotranspiration), and c) water use efficiency of soybean for different agronomic practices (Rainfed and Irrigated) and different timesteps (Arumugam, 2021) 


\section{GHG Emissions and NH3 Emissions}

Below, first the total GHG emission of milk production is explained and then the emission caused by the production of soy. Finally, a net balance is presented to summarize the effects of the $10 \%$ switch in consumption from milk protein to soy protein. The second part of this chapter describes the approach with respect to $\mathrm{NH} 3$ emissions in a similar way.

In the protein transition scenario less, milk will be produced i ( 515 ktonnes; section land use changes), and the avoided GHG emission due to this reduction has been estimated at 0.615 Mtonnes CO2-eq (total of $\mathrm{CO}_{2}, \mathrm{CH}_{4}$ and $\mathrm{N}_{2} \mathrm{O}$ emissions with GWP for $\mathrm{CH}_{4}$ of 34 and for $\mathrm{N}_{2} \mathrm{O}$ of 298). The GHG intensity parameter ( $\mathrm{g} \mathrm{CO} 2-\mathrm{eq} / \mathrm{kg} \mathrm{milk}$ ), used for this calculation (Annex 7), includes emissions due to farm inputs, such as feed and chemical fertilizer, and all emissions related to onfarm activities, but excludes emissions that occur after the milk leaves the farm ('cradle to farm gate' approach). Moreover, part of the total GHG emission of a dairy farm is attributed to the produced meat which is a co-product of dairy farming. It is thereby assumed that the lower milk production $(-3.8 \%)$ does not significantly affect the production of dairy meat in the protein transition scenario.

The additional production of soybeans for soy drink in the protein transition scenario (60.3 ktonnes; section land us changes) causes a GHG emission of 0.028 Mtonnes $\mathrm{CO}_{2}$-eq in combination with the emission intensity parameter of $470 \mathrm{~g} \mathrm{CO} 2-\mathrm{eq} / \mathrm{kg}$ soybean (Annex 7). Again, this only relates to emissions up to the farm gate. The production of soy drink also yields a small amount of a co-product that can be used as animal feed. To value this in terms of GHG emissions, the coproduct is compared with soy meal imported from South America on an equal protein basis and represents a GHG emission of 0.0053 Mtonnes $\mathrm{CO}_{2}$-eq (Annex 7). To keep our analysis as simple as possible, we assumed that this co-product would replace imported soy meal and its corresponding $\mathrm{CO}_{2}$-eq emission. The resulting $\mathrm{CO}_{2}$-eq emission from cultivating the additional soybeans in the protein transition scenario for the production of soy drink has been calculated at a net amount of 0.023 Mtonnes.

The avoided GHG emission from lower milk production is much larger than the additional GHG emission from cultivating soybeans for soy drink and the overall reduction is estimated at 0.59 Mtonnes. This reduction represents $2.2 \%$ of the total GHG emission from agriculture in the Netherlands (estimated at circa 27 Mtonnes in 2018, CBS).

In the above analysis the emissions after the farm gate, mostly due to $\mathrm{CO}_{2}$ emissions caused by energy use in processing, transport, packaging, and retail, have not been taken into account. In our analysis, we assumed that the difference in this energy use between milk products and soy drink is negligible compared to the emissions estimated in and before the farm phase. Another aspect that has been left out, relates to land use (change) with potentially large impacts on GHG emissions. This refers to the estimation of GHG emission from soy meal, but also to the final destination of the surplus land in the Netherlands, estimated above for the protein transition scenario (section land use changes). Generally, these GHG emission impacts are rather uncertain and depend on choices that producers make in a changing world. For this study, we decided to neglect these impacts, but in future work this might be added to our results.

Table 15 Overview GHG emissions with protein transition

\section{GHG footprint Protein transition $\quad$ GHG emission}

\begin{tabular}{|l|l|l|l|}
\hline & g CO2-eq/g & ktonnes/yr & ktonnes CO2-eq/yr \\
\hline Milk & 1.20 & -515 & -615 \\
\hline Soybean & 0.47 & 60.3 & 28.3 \\
\hline Soymeal & 0.62 & 8.4 & -5.3 \\
\hline Balance & & & -592 \\
\hline & & & $-2.2 \%$ \\
\hline
\end{tabular}


For the NH3 emission of milk production we looked at the $\mathrm{N}$ excretion of dairy cows, which is estimated at 212 million $\mathrm{kg} \mathrm{N}$ in 2015 (Mineralenbalans, CBS) and at their total NH3 emission from manure in housing and processing, during grazing and after application of the dairy manure to soils (39 million $\mathrm{kg} \mathrm{NH3}$ in 2015, EmissieRegistratie). Next, we assume that the $\mathrm{N}$ excretion is reduced proportional to the decline of the milk production and related feed intake in the scenario with the $10 \%$ shift in protein consumption. This leads to a lower NH3 emission of 1.5 million $\mathrm{kg}$ at an annual basis (Table 12). The second major NH3 source is the use of synthetic fertilizer and its specific NH3 emission after application to soils has been estimated at $46 \mathrm{~g} \mathrm{NH} 3 / \mathrm{kg} \mathrm{N}$, based on a total $\mathrm{NH3}$ emission of 11.3 million $\mathrm{kg}$ and a total synthetic $\mathrm{N}$ fertilizer use of 245 million $\mathrm{kg}$ (CBS and EmissieRegistratie). Combining the lower demand for grass, silage maize and wheat in the protein transition scenario and estimations of their synthetic fertilizer uses, gives a total of 0.2 million $\mathrm{kg} \mathrm{NH3}$ emission reduction. This brings the total decline to 1.7 million $\mathrm{kg}$ due to the lower milk production (Iable 12). For simplicity reasons, we have assumed that soybean is produced without $\mathrm{N}$ fertilizers, which means that the $\mathrm{NH}$ emission for cultivating soybean is zero. The net reduction in $\mathrm{NH} 3$ emission now amounts to 1.7 million $\mathrm{kg}$, which equals $1.5 \%$ of the total $\mathrm{NH} 3$ emission from agriculture, forestry and fisheries in The Netherlands, in 2015 (EmissieRegistratie).

Table 16 Overview NH3 emissions Netherlands

\begin{tabular}{|c|c|c|c|c|}
\hline \multirow{2}{*}{$\begin{array}{l}\text { Netherlands, } 2015 \\
\text { Manure }\end{array}$} & \multicolumn{2}{|c|}{ Activity data } & \multicolumn{2}{|c|}{ NH3 emission } \\
\hline & $\mathbf{m l n} \mathbf{~ k g}$ & & g NH3/kg & mln kg \\
\hline Milking cows & 211.5 & & 185 & 39.1 \\
\hline Protein transition & -8.0 & & & -1.49 \\
\hline Fertilizer & 1000 ha & kg N/ha & & \\
\hline Grass & -21.1 & 145 & 46.0 & -0.141 \\
\hline Silage maize & -5.1 & 37.3 & & -0.0088 \\
\hline Wheat & -10.7 & 154 & & -0.076 \\
\hline Soya bean & 20.1 & 0 & & 0 \\
\hline \multirow[t]{2}{*}{ Totals } & & & & -1.71 \\
\hline & & & & $-1.5 \%$ \\
\hline
\end{tabular}


In this reflection chapter we discuss the general outcomes for both countries in combination with the main objective. We address several points in this chapter:

- $\quad$ Outcomes (are we seeing expected changes?)

- Approach of calculating a protein transition (does it have added value?)

- Differences between our two countries (does the approach help with reviewing their national situations?)

\subsection{Ethiopia Case Summary and Reflections}

The diets of small holder farmers in Ethiopia are dominated by cereals and are often short on proteins. Food groups such as root crops, meat, oils, and fish are often completely missing. These data are from the REALISE programme that conducted diet diversity score studies in 4 regions and over 60 woredas (REALISE, 2021). Considering this, a transition to more soybean has the potential to increase diet diversity, as soy is both a protein-rich pulse and an oil crop. The Soy 10 project looked at the consequences of shifting $10 \%$ of the protein intake from cereals to soy.

The start the cereal food supply at the national level was reduced with $10 \%$ and the soy food supply was increased such that total food protein supply for the country remained constant. In this protein transition, $10 \%$ of the cereal food protein supply is thus replaced by the same amount of protein from soy (in absolute units).

The diet transition scenario, replacing $10 \%$ of the cereal protein consumption by soybean proteins leads to a drop in available calories of roughly $100 \mathrm{kcal} / c a p i t a$ per day on an average total supply of circa 2330 in the whole diet $(-5 \%)$. Total fat supply amounts to $27 \mathrm{~g} / \mathrm{cap} /$ day (whole diet) in the current situation (2017) and would increase with $1.3 \mathrm{~g} / \mathrm{cap} /$ day $(+5 \%)$ in the protein transition scenario. Overall, the food situation in Ethiopia is still a challenge for large parts of the population, so lower calorie supply is not what is aimed for.

The protein transition could free up around 0.8 Mha of harvested crop areas, which is circa $4.4 \%$ of all harvested areas on cropland in Ethiopia. The overall land situation, the land is relatively scarce in Ethiopia, therefore more land available could be a wished outcome of shifting towards protein rich crops. However again, it must be considered by policy makers if the decline in land use for protein production for crops is a scenario that is wished for the country. It might be that reaching the calorie target is more important than the protein target. Also, it might be that incorporating more vegetables into the land use could be a target. The free land could also be used for other purposes than crop production (e.g., building areas).

The next factor is water use, it seems that there is little effect on the protein transition looking at the shift to crops. Connecting that to the general situation in Ethiopia, it is a land-locked country, depending on water resources that are highly variable. This including climate change, which often leads to a more water insecure situation, (higher intensities of rainfall and higher frequencies of draught) could lead to a more insecure water supply. However, in this research it did not matter that much for the water use which crop (cereal or soy) there was planted.

Overall, we can conclude that the dietary transition of the proteins would not lead to major changes in water availability, and that according to the current projections the shift would not suffer from rainfall deficits in the future; however, it is still necessary to further analyse model outcomes to better understand these results. Overall, the diet transition does not seem to lead to large changes 
in irrigation demand, and seems resilient to changes in climate as projected by this specific climate scenario

As side note can be said that Ethiopia has the potential to greatly increase its rainfed yields and thereby its food production by intensifying its crop production. Yields in the main season could be increased by a factor three up to a factor nine depending on the crop. Such a productivity increase could improve Ethiopia's food security without the need for agricultural land expansion.

Moving to the GHG emissions, the calculated results show a decrease of $11 \%$ to a protein transition. However, this outcome seems not in line with expectations and therefore require further investigations.

Reflecting on the future with respect to climate change, in this project context soybean seems a more climate resilient crop than cereals under this specific climate scenario. Soybean's yield seems to remain constant while the yields of the relevant cereals are projected to decline. It therefore can be concluded that the savings on land because of the dietary transition from cereals to soybean could be maintained and possibly even increased in the future despite climate change. As the future is more uncertain and needs to have tailored approaches. One of these options could be giving farmers access to different varieties of a crop increases strategic options. More varieties with different lengths of growing season, and different water requirements could have an impact on climate resilience.

As can be seen, there are many factors and considerations to be reflected on. Therefore, more needs to be researched. This is presented in section 10.4

\subsection{The Netherlands Case Summary and Reflections}

Cow milk production and consumption in the Netherlands puts significant pressure on the climate and the environment. Part of the pressure origins from the large emissions of methane and ammonia. Methane is a powerful greenhouse gas and the most important contributor to global warming after CO2. The other gas, Ammonia, reduces the air quality and has negative consequences for the biodiversity and (ground)water quality. Therefore, a reduction of milk consumption and production could potentially have lots of benefits.

Moving to the first aspect, the diet. A diet with protein from soymilk instead of cowmilk reduces the fat, sugar and calory intake as can be seen from our calculations. For most Dutch people this will be an improvement of their diet. This is because the intake of fat and amount of energy is too high for the current lifestyle of an average Dutch citizen. The key benefit of limiting dairy products is the reduction of the intake of animal fats which limits the intake of saturated fats and cholesterol. Natural Soy milk however contains much less calcium and Vitamin B12. Many fortified Soymilk products have additional $\mathrm{Ca}$ and vitamins. Another option to reduce fat intake, is switching to drinking skim milk products from which all fat is removed. However, this still include the environmental impact of the production of the milk.

Moving to the land use, a $10 \%$ reduction of milk consumption will reduce the number of cows and could potentially make grassland available for other land use and potentially land which is used to produce feed for the cows. Around $16 \mathrm{Kha}$ will be available resulting from land from combined grassland, wheat, and silage maize cultivation in the scenarios taken in this study. This land could potentially be used for soy production needed for soy milk. Most of the current grasslands in the Netherlands cannot be used for soy production. However, if these lands are taken out of intensive grazing there could be many environmental benefits. Especially if this is peatland the artificial lowering of the water table can be limited which reduce peatland degradation and reduces $\mathrm{CO} 2$ emissions. 
In terms of water usage, silage maize and wheat might need more water than the current situation to produce 1 tonne in the future. However, soybean and grassland are projected to require less water than the current due to optimal climate conditions in the future (an increase in temperature is optimal for soybean and grassland).

The next indicator is greenhouse gas emissions. Limiting the number of Cows will reduces greenhouse gas emissions. Methane emissions from cows will be reduced and there will be less CO2 emission from grasslands and feed producing land. Direct emissions for the avoided GHG emission from lower milk production is much larger than the additional GHG emission from cultivating soybeans for soy drink and the overall reduction is estimated at 0.59 MTonnes. This reduction represents $2.2 \%$ of the total GHG emission from agriculture in the Netherlands. Also, the $\mathrm{NH} 3$ emissions will decrease by $1.5 \%$. This a relatively small number but within the current nitrogen crisis all decreases of $\mathrm{N}$ emissions will help.

Although Soy production is possible in the Netherlands the yields are relatively low. It is in general too cold in the Netherlands to grow soy with high protein contents. With future climate change, the temperatures will become more favourable for soy production. Also, in the future, temperatures will still be sub-optimal for soy production. Moreover, in the future the yields of soy will be low with relatively low protein contents.

When reflecting on the environment, the environmental impacts of soy production are considerably lower compared to milk production form grasslands. However, direct replacement of grassland by soy producing land is not possible. In the Netherlands soy can only be grown in the polders or on sandy soils. A change of cow Milk to Soy has many environmental benefits but the benefit will be more indirectly instead of directly and it remains the question to what extent large scale soy production in the Netherlands is possible even in a warming climate.

Understanding the indirect impacts of climate change on food security requires more comprehensive analytical approaches and sophisticated modelling, including links to the political economy. This study investigated the national level land requirement and climate change impacts on production for cereal and fodder crops using a biophysical and empirical modelling approach. However, we have not investigated location-specific information on the suitability and production of cereals and fodder crops.

\subsection{Similarities and Difference between Protein Transition in Ethiopia and The Netherlands}

In this research we have reflected on two countries in two very different positions in the protein transition. We have found some similarities in the conclusions between the countries but also differences. The similarities are mostly focused on that a protein transition would free up land, and as both countries have high pressure on land, this is therefore considered a positive development. On the other side, the transition would not have a significant impact on the GHG emissions and the water use. The differences in conclusions focus mostly on the impact on the diets and climate change. As in the Netherlands, a decline in fat and calories is wished effect of a protein transition, however it is in Ethiopia not wished in all cases, as big parts of the countries are still food insecure. With respect to climate change, it seems in Ethiopia the yields will increase for soy with climate change. In the Netherlands, the soy yield will increase but with less protein content and higher fat content. This could have an effect of the initial positive impact of decreasing fat. 


\subsection{General Reflections}

Moving to the question if using soy is useful for calculations on a protein transition and help reflect on it. We argue that our approach helps to reflect in an integrative and quantified manner. The approach does not only focus on one impact on the indicators but several components. However, we also recognize this is the start of a methodology and more development is needed. More indicators need to be included to make it more complete, such as including micronutrients, groundwater use, other GHG. More elaboration on the current methodology and indicators is explained in the text below.

\section{- Diet}

What the current methodology does support is reflecting on the current diet situation and what is a desired transition in the diet pattern might include. With the calculations, it can reflect on the answering questions on macronutrients changes. However, including micronutrients would give a more complete vision for impacts on health.

- $\quad$ Land use

The methodology we use can be followed as an example to get more first insights. For further development, it is useful for the Ethiopia to include not only cells where both soy and cereals are harvested but also that there would be a possibility for expansion.

- Water use

For both cases different models were used to calculate the water use for the crops. For specific methodology both technical reports can be used (Hermelink and Conijn, 2021) and Arumugam, 2021. Also, this approach can be used as a start for getting more insights in the water use. For this research we did not include groundwater changes for irrigation, which is an important indicator of sustainable water use.

\section{- $\quad$ GHG emissions}

For this research we have only addressed the $\mathrm{N}$ changes as we expect there are the most emissions (see assumptions). However, when using the methodology for other protein transitions, other changes might be more important such as a transition to a non-nitrogen fixating crop. Then fertilizer is needed, this affects the $\mathrm{N}$ amount and thus the GHG emissions.

\subsection{Follow-Up Research}

Some general directions for follow-up research are needed to enrich the methodology and to explore alternative scenarios for the possibilities of a protein transition in different countries.

\section{Elaborating on possible future scnearios}

The current analyses were done for a scenario where $10 \%$ of the protein source was shifted. It would be informative to explore the impact of a greater shift of for example $50 \%$ on land use and other explored variables. This could open a lot more land for other purposes.

\section{Elaborating on methodology}

Future explorations should also involve the impact that such a transition would have on the overall diet, as other macro and micronutrient demands also still need to be covered. Also including a water availability study would be helpful to understand if a transition leads to more water stress or more water availability. To do this, also groundwater use should be indicated. 


\section{Technical follow up research case}

The following points need attention before future explorations can be done. The technical follow up are connected to specifically 1 case. However, this does not mean that it is exclusively linked to that case. The following explorations would shed more light on the possible impact of a transition in protein source (both technical follow ups are originating from the technical reports of Hermelink and Conijn, 2021 and Arumugam 2021):

Ethiopia-Thus far, the averages of yields, growing days, and water balance components were computed for all cells where either a cereal or soybean was growing. However, the shift of cereal area to soy area was done only in cells where there was already soy growing, to ensure that soy could grow in the areas where the increased area was placed. It would therefore be informative to analyse the differences between the scenarios only in the cells where the shift from cereals to soybean took place, rather than to include all cells where cereals were grown but not soybean. This would give a more realistic comparison of how the crops perform relative to each other specifically in the relevant areas.

Ethiopia- The current analyses were done for a scenario where $10 \%$ of the cereal protein source was replaced by soybean. It would be informative to explore the impact of a greater replacement of for example $50 \%$ on land use and other explored variables. This could open up a lot more land for other purposes. However, this exploration should also involve the impact that such a shift would have on the overall diet, as other macro and micronutrient demands also still need to be covered

Netherlands- This study investigated the national level land requirement and climate change impacts on production for cereal and fodder crops using a biophysical and empirical modelling approach. However, we have not investigated location-specific information on the suitability and production of cereals and fodder crops. Integrated crop modelling and suitability modelling approach could be the best opting methodology to find soy production suitability, which requires in soy transition. Location-specific information on suitability could help to avoid misleading on choosing land for alternative cultivation.

Netherlands- Linking crop models with economic models and approaches, crop model outputs can be effectively used as inputs into socioeconomic modelling efforts for priority setting and policy advice using ex-ante impact assessment of technologies and scenario analysis. Bio-economic models are used for exploratory studies to understand the potential impacts of drivers, for instance, climate change and alternative crop management practices. 


\section{References}

Aiking, H., \& de Boer, J. (2020). The next protein transition. Trends in Food Science \& Technology, 105, 515-522.

Analysis of Soybean Value Chain Development in South Western Ethiopia. By Wondimu Tesfaye and Prof. Dr. Gezahegn Berecha, n.d.

Arumugan, P., Ludwig, F., Chevuru, S., \& I.S. (2021, November). Modeling Crop Yields and Water Balances for the Netherlands with WOFOST.

Bekele, M., Zewdie, S., Boissière, M., \& Atmadja, S. (2019). REDD+ MRV implementation in Ethiopia: Review of the context, framework and progress.

Berhanu, Y., Olav, L., Nurfeta, A., Angassa, A., \& Aune, J. B. (2019). Methane emissions from ruminant livestock in Ethiopia: Promising forage species to reduce $\mathrm{CH} 4$ emissions. Agriculture, $9(6), 130$.

Boer, H.C. de, M.M. van Krimpen, H. Blonk, M. Tyszler, 2014. Replacement of soybean meal in compound feed by European protein sources- Effects on carbon footprint. Wageningen, Wageningen UR (University \& Research centre) Livestock Research, Livestock Research Report 819.

CBS. (2015). Kaart bodemgebruik van Nederland, 2015 | Compendium voor de Leefomgeving. Compendium Voor de Leefomgeving. Retrieved December 23, 2021, from https://www.clo.nl/indicatoren/nl0061-bodemgebruikskaart-voor-nederland

Centraal Bureau voor de Statistiek. (2014, August 15). Achtergrondinformatie en handelsstromen (soja). Retrieved December 2, 2021, from https://www.cbs.nl/nl$\mathrm{nl} /$ achtergrond/2014/33/achtergrondinformatie-en-handelsstromen--soja-

Centraal Bureau voor de Statistiek. (2014, August 15). Achtergrondinformatie en handelsstromen (soja). Retrieved December 2, 2021, from https://www.cbs.nl/nl$\mathrm{nl} /$ achtergrond/2014/33/achtergrondinformatie-en-handelsstromen--soja-

Chai, R., Ye, X., Ma, C., Wang, Q., Tu, R., Zhang, L., \& Gao, H. (2019). Greenhouse gas emissions from synthetic nitrogen manufacture and fertilization for main upland crops in China. Carbon balance and management, 14(1), 1-10.)

Dagevos, H., Verhoog, D., van Horne, P., \& Hoste, R. (2018). Vleesconsumptie per hoofd van de bevolking in Nederland, 2005-2017 (No. 2018-108). Wageningen Economic Research.

Desissa, D. H. (2019). Soybean research and development in Ethiopia. Acta Scientific Agriculture, 3, 192-194.

Dietary guidelines and sustainability. (2010). Food and Agriculture Organization of the United Nations. Retrieved December 15, 2021, from https://www.fao.org/nutrition/education/fooddietary-guidelines/background/sustainable-dietary-guidelines/en/

FAO. (2016). Country profile - Ethiopia. https://www.fao.org/3/i9732en/I9732EN.pdf Food and Landuse coalition. (n.d.). The food and landuse coalition. Retrieved December 15, 2021, from https://www.foodandlandusecoalition.org/country/ethiopia/ 
Gustavsson, D., C. Cederberg, U. Sonesson, R. van Otterdijk and A. Meybeck, 2011. Global food losses and food waste: Extent, causes and prevention. FAO, Rome.

HAMBISA, E. N., \& GEDA, M. B. (2019). Analysis of soybean value chain in Buno Bedele zone, south western Ethiopia. Ethiopian Journal of Environmental Studies \& Management, 12(5).

Hermelink, M., Conijn S. (2021, June). Modelling Crop Yields and Water Balances for Ethiopia with LPJmL.

https://nl.wikipedia.org/wiki/Sojamelk; accessed; 16-03-2021

Https://Www.Wateetnederland.NI/Resultaten/Voedingsmiddelen/Consumptie. Retrieved

December 2, 2021, from

https://www.wateetnederland.nl/resultaten/voedingsmiddelen/consumptie

Ministry of foreign affairs Netherlands, Ministry of agriculture Ethiopia, \& Wageningen University and Research. (2021, April 6). REALISE - Bilateral Ethiopian Netherlands Effort for Food Income \& Trade. BENEFIT. https://benefitethiopia.org/category/news/realise/

NZO, 2020. Broeikasgassen in de Nederlandse zuivelsector. Available at:

https://www.nzo.nl/wp-content/uploads/2020/01/NZO-Factsheet-Broeikasgassen-in-deNederlandse-zuivelsector-jan-2020.pdf

Polley, H.W., Johnson, H.B., Mayeux, H.S., 1997. Leaf physiology, production, water use, and nitrogen dynamics of the grassland invader Acacia smallii at elevated $\mathrm{CO} 2$ concentrations. Tree Physiology 17, 89-96.

Reijnders, L., \& Soret, S. (2003). Quantification of the environmental impact of different dietary protein choices. The American journal of clinical nutrition, 78(3), 664S-668S.

Rijksinstituut voor Volksgezondheid en Milieu Ministerie van Volksgezondheid, Welzijn en Sport. (2016). Consumptie van voedingsmiddelen.

Rockstrom, J., 2000. Water resources management in smallholder farms in eastern and southern Africa, an overview. Physics and Chemistry of the Earth Part B-hydrology Oceans and Atmosphere 275-283.

Sheehy, T., Carey, E., Sharma, S., \& Biadgilign, S. (2019). Trends in energy and nutrient supply in Ethiopia: a perspective from FAO food balance sheets. Nutrition journal, 18(1), 1-12.

Tallentire, C. W., Mackenzie, S. G., \& Kyriazakis, I. (2018). Can novel ingredients replace soybeans and reduce the environmental burdens of European livestock systems in the future?. Journal of Cleaner Production, 187, 338-347.

Tao, F., Zhang, Z., 2011. Impacts of climate change as a function of global mean temperature: maize productivity and water use in China. Climatic Change 105, 409-432.

Tesfaye, A., AdaneArega, B. A., Degu, T., \& Hailemariam, M. Progresses in Breeding and Genetic Improvement of Soybean in Ethiopia: A Review. Ethiopian Journal of Crop Science.

Timmer, R. (n.d.). Hoe teel je soja in Nederland? WUR. Retrieved December 2, 2021, from https://www.wur.nl/nl/artikel/Hoe-teel-je-soja-in-Nederland.htm

Timmer, R.D. \& C.L.M. de Visser (2014). Ontwikkeling van de sojateelt in Noord-Nederland. Praktijkonderzoek Plant \& Omgeving, Wageningen UR Business Unit Akkerbouw, Groene Ruimte en Vollegrondsgroenten. PPO nr. 3250296300. December 2014. 
Vergelijking met normen van macronutriënten. (2016). Voedselconsumptiepeiling.

https://www.wateetnederland.nl/resultaten/energie-en-macronutrienten/vergelijking-met-denormen

WHO. (2020, April 29). Healthy diet. World Health Organization. Retrieved December 15, 2021, from https://www.who.int/news-room/fact-sheets/detail/healthy-diet

World Bank. (2010). Agricultural nitrous oxide emissions (thousand metric tons of $\mathrm{CO} 2$ equivalent) - Ethiopia | Data. The World Bank Data. Retrieved December 7, 2021, from https://data. worldbank.org/indicator/EN.ATM.NOXE.AG.KT.CE?end $=2008 \&$ locations $=$ ET\&start $=1$ 970\&view=chart

World Development Indicators (WDI), November 2014 - Ethiopia Data Portal. (2014, December 11). Ethiopia FAO STAT - Land Use and Agricultural Inputs. Retrieved December 13, 2021, from https://ethiopia.opendataforafrica.org/mbhpan/world-development-indicators-wdi-november2014 


\section{Annex 1 Food Balance Sheet (FAO)}

FAO's short explanatory text of the Food Balance Sheet database

Food Balance Sheet presents a comprehensive picture of the pattern of a country's food supply during a specified reference period. The food balance sheet shows for each food item - i.e. each primary commodity and a number of processed commodities potentially available for human consumption - the sources of supply and its utilization. The total quantity of foodstuffs produced in a country added to the total quantity imported and adjusted to any change in stocks that may have occurred since the beginning of the reference period gives the supply available during that period. On the utilization side a distinction is made between the quantities exported, fed to livestock, used for seed, put to manufacture for food use and non-food uses, losses during storage and transportation, and food supplies available for human consumption. The per caput supply of each such food item available for human consumption is then obtained by dividing the respective quantity by the related data on the population actually partaking of it. Data on per caput food supplies are expressed in terms of quantity and - by applying appropriate food composition factors for all primary and processed products - also in terms of caloric value and protein and fat content. (see: http://www.fao.org/faostat/en/\#data/FBS) 


\section{Annex 2 Diet, Production, and Land Use (Ethiopia, 2017)}

Table 17 Results of the calculation to assess the effects on the production of replacing $10 \%$ of cereal protein intake by the same absolute amount of soybean protein.

\begin{tabular}{|c|c|c|c|c|c|c|c|c|c|}
\hline \multirow{2}{*}{$\begin{array}{l}\text { Food Balance sheet (Ethiopia, 2017) } \\
\text { Element }\end{array}$} & \multicolumn{3}{|c|}{ Cereals - Excluding Beer } & \multicolumn{3}{|c|}{ Soybeans } & \multicolumn{3}{|c|}{ Total (cereals + soy) } \\
\hline & 2017 & $-10 \%$ & ratio & 2017 & $-10 \%$ & ratio & 2017 & $-10 \%$ & ratio \\
\hline Fat supply quantity (g/capita/day) & 6.67 & 6.00 & 0.900 & 0.17 & 2.15 & 12.6 & 6.84 & 8.15 & 1.19 \\
\hline Protein supply quantity (g/capita/day) & 41.84 & 37.66 & 0.900 & 0.36 & 4.54 & 12.6 & 42.2 & 42.2 & 1.00 \\
\hline Food supply (kcal/capita/day) & 1553 & 1398 & 0.900 & 3 & 38 & 12.6 & 1556 & 1436 & 0.923 \\
\hline Food supply quantity (kg/capita/yr) & 171.7 & 154.5 & 0.900 & 0.35 & 4.42 & 12.6 & 172.1 & 159 & 0.924 \\
\hline Food $(1000 \text { tonnes } / y)^{1}$ & 18271 & 16444 & 0.900 & 37 & 470 & 12.6 & 18308 & 16914 & 0.924 \\
\hline Residuals & -2 & -2 & 1.000 & 0 & 0 & & & & \\
\hline Other uses (non-food) & 6079 & 6079 & 1.000 & 0 & 0 & & & & \\
\hline Processing & 424 & 424 & 1.000 & 0 & 0 & & & & \\
\hline Seed & 471 & 471 & 1.000 & 1 & 1 & 1.00 & 472 & 472 & 1.000 \\
\hline Feed & 1213 & 1213 & 1.000 & 0 & 0 & & & & \\
\hline Losses & 878 & 817 & 0.931 & 6 & 74 & 12.3 & 884 & 892 & 1.009 \\
\hline Domestic supply quantity & 27334 & 25446 & 0.931 & 44 & 545 & 12.3 & 27378 & 25992 & 0.949 \\
\hline Export Quantity & 44 & 44 & 1.000 & 54 & 54 & 1.00 & 98 & 98 & 1.000 \\
\hline Stock Variation & 411 & 411 & 1.000 & 0 & 0 & & & & \\
\hline Import Quantity & 1905 & 1905 & 1.000 & 0 & 0 & & & & \\
\hline Production (1000 tonnes/y) & 25884 & 23996 & 0.927 & 98.3 & 599 & 6.10 & 25982 & 24596 & 0.947 \\
\hline
\end{tabular}

${ }^{1}$ All categories from Food up to Production are expressed in ktonnes per year of primary commodities.

18Results of linking the production changes due to the $10 \%$ protein replacement (see Table 2.1x) on production and harvested areas.

\begin{tabular}{|c|c|c|c|c|c|c|c|c|c|}
\hline \multirow[t]{2}{*}{ Some consequences for production and areas } & \multicolumn{3}{|c|}{ Cereals - Excluding Beer } & \multicolumn{3}{|c|}{ Soybeans } & \multicolumn{3}{|c|}{ Total (cereals + soy) } \\
\hline & 2017 & $-10 \%$ & ratio & 2017 & $-10 \%$ & ratio & 2017 & $-10 \%$ & ratio \\
\hline \multicolumn{10}{|l|}{ Production (1000 tonnes) } \\
\hline All raster cells (MAPSPAM) & 25492 & 23604 & 0.926 & 86.7 & 588 & 6.783 & 25578 & 24192 & 0.946 \\
\hline Only cells where both crops are harvested & 7092 & 5204 & 0.734 & 86.6 & 588 & 6.784 & 7179 & 5792 & 0.807 \\
\hline Difference & & -1888 & & & 501 & & & -1387 & \\
\hline \multicolumn{10}{|l|}{ Harvested area (kha) } \\
\hline All raster cells (MAPSPAM) & 10351 & 9546 & 0.922 & 38.4 & 360 & 9.368 & 10390 & 9905 & 0.953 \\
\hline Only cells where both crops are harvested & 3026 & 2220 & 0.734 & 38.4 & 360 & 9.374 & 3064 & 2580 & 0.842 \\
\hline Difference & & -805 & & & 321 & & & -484 & \\
\hline
\end{tabular}




\section{Annex 3 Crop Yield Maps (Ethiopia, 2017)}

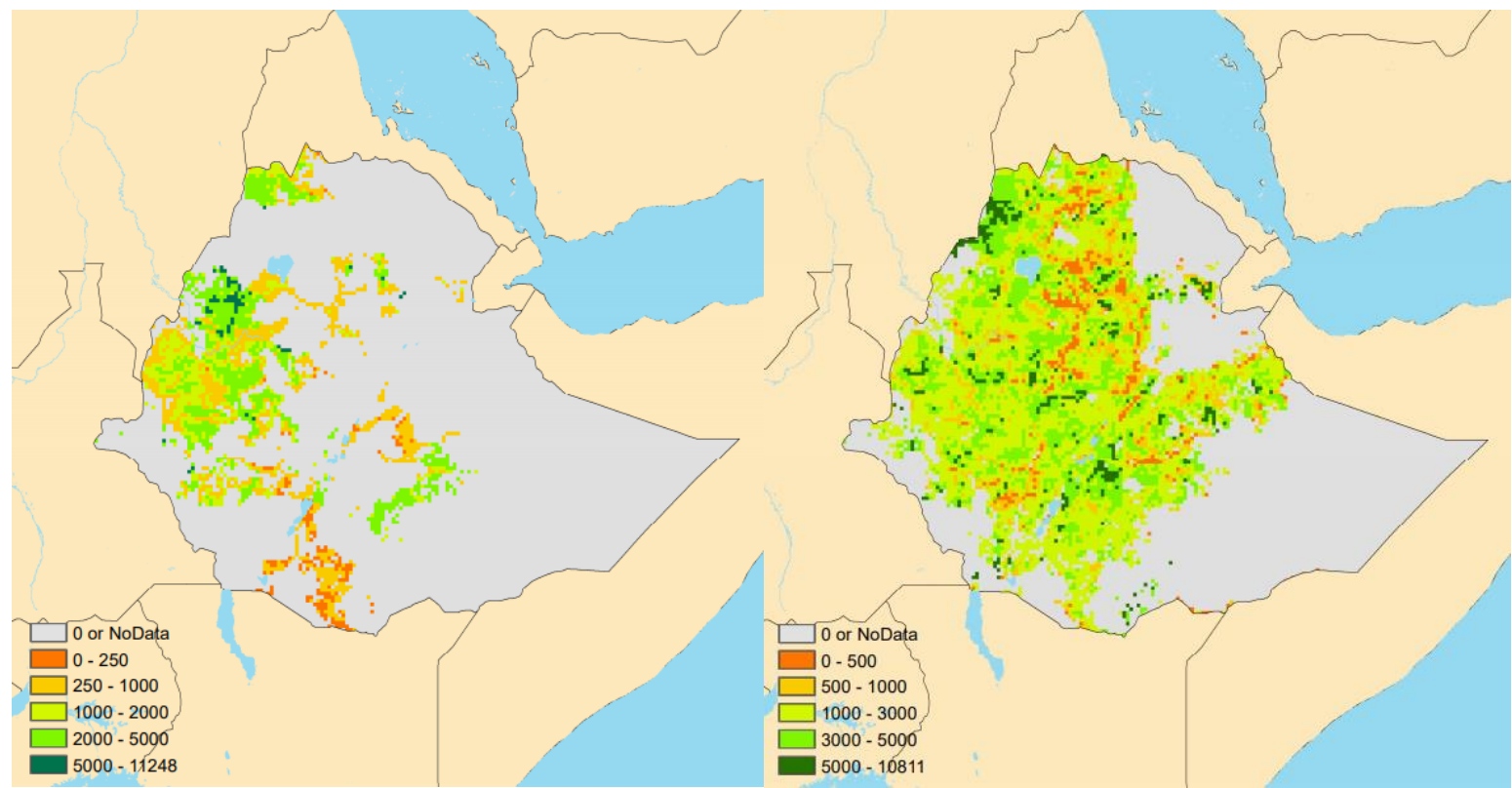

Figure 3.1. Crop yields of soybean (left) and cereals (right) in $\mathrm{kg} / \mathrm{ha}$ per raster cell in 2017. 


\section{Annex 4 Alternative Method for Land Use of Soybean (Ethiopia, 2017)}

Alternative method to adjust the soy area map in the protein transition scenario for Ethiopia

Adjusted harvested area maps can be constructed by multiplying change fractions (1900/7100 or 0.734 for cereals and $501 / 87$ or 6.78 for soybeans; Annex 2, Table 2.2) with the "original" (2017) harvested areas in the subset of raster cells (all other cells remain unchanged). Cereal and soybean productions per cell were calculated by multiplying the adjusted harvested area maps in the protein transition scenario with the yield maps that were supplied via the MAPSPAM data. This method implicitly assumes that the production conditions per ha in the protein transition scenario are not different from the original situation in 2017. National land use in the protein transition scenario is reduced by almost 600,000 ha relative to the situation in $2017(-5.6 \%$ of total land for cereals and soybeans in 2017), as a result of $-800,000$ ha for cereals and $+220,000$ ha for soybeans. However, the consequences for land use at individual cell level differs widely, due to differences in the original land used by cereals and soybeans in 2017 (Figure 2, left). The resulting area map shows that a small number of cells require more land in the protein transition scenario because the surplus land from cereals is less than the additional required land for soybeans.

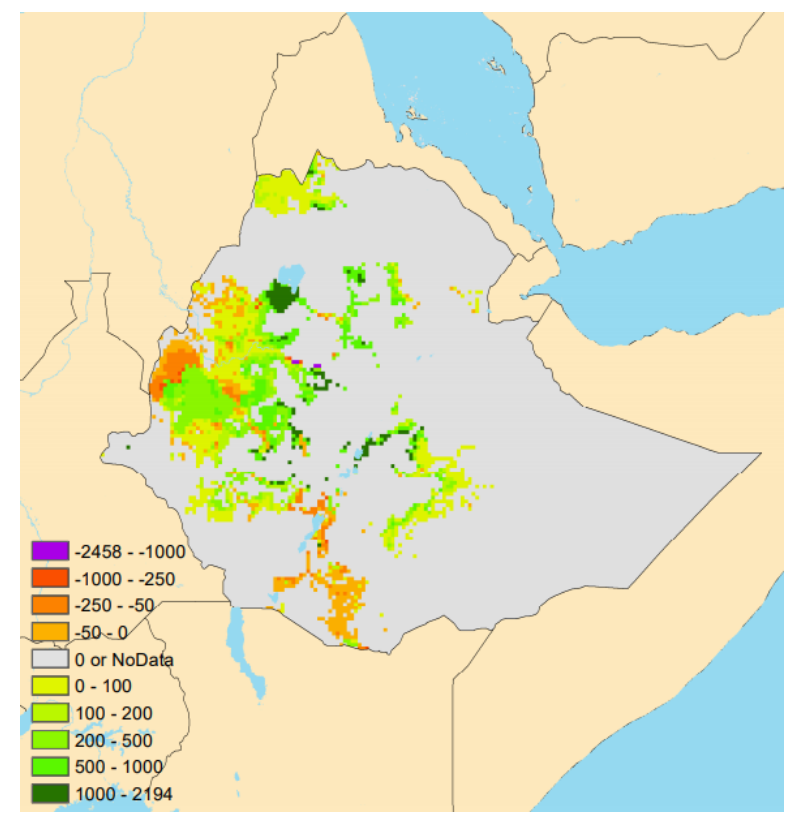

Figure 16 . Difference between total land use of cereals and soybean in 2017 and the land use after $10 \%$ protein adjustment in ha per raster cell. Negative and positive values indicate respectively more or less land needed in the protein transition scenario. 
Table 19 Results of linking the production changes due to the $10 \%$ protein replacement (see Annex 2, Table 2.1) on production and harvested areas.

\begin{tabular}{|c|c|c|c|c|c|c|c|c|c|}
\hline \multirow[t]{2}{*}{$\begin{array}{l}\text { Some consequences for } \\
\text { production and areas }\end{array}$} & \multicolumn{3}{|c|}{$\begin{array}{l}\text { Cereals - } \\
\text { Excluding Beer }\end{array}$} & \multicolumn{3}{|c|}{ Soybeans } & \multicolumn{3}{|c|}{$\begin{array}{l}\text { Total (cereals + } \\
\text { soy) }\end{array}$} \\
\hline & 2017 & $\begin{array}{l}- \\
10 \\
\%\end{array}$ & $\begin{array}{l}\text { rati } \\
0\end{array}$ & $\begin{array}{l}20 \\
17\end{array}$ & $\begin{array}{l}- \\
10 \\
\%\end{array}$ & $\begin{array}{l}\text { rati } \\
0\end{array}$ & $\begin{array}{l}201 \\
7\end{array}$ & $\begin{array}{l}- \\
10 \%\end{array}$ & $\begin{array}{l}\text { rati } \\
0\end{array}$ \\
\hline \multicolumn{10}{|l|}{ Production (1000 tonnes) } \\
\hline All raster cells (MAPSPAM) & 25492 & $\begin{array}{l}236 \\
04\end{array}$ & $\begin{array}{l}0.9 \\
26\end{array}$ & $\begin{array}{l}86 . \\
7\end{array}$ & 588 & $\begin{array}{l}6.7 \\
83\end{array}$ & $\begin{array}{l}255 \\
78\end{array}$ & $\begin{array}{l}241 \\
92\end{array}$ & $\begin{array}{l}0.9 \\
46\end{array}$ \\
\hline $\begin{array}{l}\text { Only cells where both crops } \\
\text { are harvested }\end{array}$ & 7092 & $\begin{array}{l}520 \\
4\end{array}$ & $\begin{array}{l}0.7 \\
34\end{array}$ & $\begin{array}{l}86 . \\
6\end{array}$ & 588 & $\begin{array}{l}6.7 \\
84\end{array}$ & $\begin{array}{l}717 \\
9\end{array}$ & $\begin{array}{l}579 \\
2\end{array}$ & $\begin{array}{l}0.8 \\
07\end{array}$ \\
\hline Difference & & $\begin{array}{l}- \\
188 \\
8\end{array}$ & & & 501 & & & $\begin{array}{l}- \\
138 \\
7\end{array}$ & \\
\hline \multicolumn{10}{|l|}{ Harvested area (kha) } \\
\hline All raster cells (MAPSPAM) & 10351 & $\begin{array}{l}954 \\
6\end{array}$ & $\begin{array}{l}0.9 \\
22\end{array}$ & $\begin{array}{l}38 . \\
4\end{array}$ & 260 & $\begin{array}{l}6.7 \\
80\end{array}$ & $\begin{array}{l}103 \\
90\end{array}$ & $\begin{array}{l}980 \\
6\end{array}$ & $\begin{array}{l}0.9 \\
44\end{array}$ \\
\hline $\begin{array}{l}\text { Only cells where both crops } \\
\text { are harvested }\end{array}$ & 3026 & $\begin{array}{l}222 \\
0\end{array}$ & $\begin{array}{l}0.7 \\
34\end{array}$ & $\begin{array}{l}38 . \\
4\end{array}$ & 260 & $\begin{array}{l}6.7 \\
84\end{array}$ & $\begin{array}{l}306 \\
4\end{array}$ & $\begin{array}{l}248 \\
1\end{array}$ & $\begin{array}{l}0.8 \\
10\end{array}$ \\
\hline Difference & & $\begin{array}{l}- \\
80 \\
5\end{array}$ & & & $\begin{array}{l}22 \\
2\end{array}$ & & & - & \\
\hline
\end{tabular}




\section{Annex 5 Diet and Production (The Netherlands, 2015)}

Table 20 Results of the calculation to assess the effects on the production of replacing $10 \%$ of milk protein intake by the same absolute amount of soy drink protein.

Food Balance sheet Milk - Excluding Butter

(Netherlands,

2015)

\begin{tabular}{|c|c|c|c|c|c|c|c|c|c|}
\hline Element & 2015 & $-10 \%$ & ratio & 2015 & $-10 \%$ & ratio & 2017 & $-10 \%$ & ratio \\
\hline $\begin{array}{l}\text { Fat supply } \\
\text { quantity } \\
\text { (g/capita/day) }\end{array}$ & 26.61 & 23.95 & 0.900 & 0.00 & 1.754 & & 26.61 & 25.70 & 0.966 \\
\hline $\begin{array}{l}\text { Protein supply } \\
\text { quantity } \\
\text { (g/capita/day) }\end{array}$ & 30.7 & 27.63 & 0.900 & 0.00 & 3.070 & & 30.70 & 30.70 & 1.00 \\
\hline $\begin{array}{l}\text { Food supply } \\
\text { (kcal/capita/day) }\end{array}$ & 458 & 412 & 0.900 & 0.00 & 2.544 & & 458.00 & 414.74 & 0.906 \\
\hline \multirow{2}{*}{$\begin{array}{l}\text { Food supply } \\
\text { quantity } \\
\text { (kg/capita/yr) }\end{array}$} & 303.9 & 273.5 & 0.900 & 0.0 & 32.0 & & 303.89 & 305.52 & 1.005 \\
\hline & & & & Soybeans ${ }^{2}$ & & & & & \\
\hline $\begin{array}{l}\text { Food }^{1}(1000 \\
\text { tonnes } / y)^{3}\end{array}$ & 5147 & 4633 & 0.900 & 2.0 & 62.3 & & & & \\
\hline Residuals & -6 & -6 & 1.000 & -623 & -623 & & & & \\
\hline $\begin{array}{l}\text { Other uses (non- } \\
\text { food) }\end{array}$ & 0 & 0 & \#DIV/O! & 0 & 0 & & & & \\
\hline Processing & 3585 & 3585 & 1.000 & 3138 & 3138 & & & & \\
\hline Seed & 0 & 0 & \#DIV/O! & 0 & 0 & & & & \\
\hline Feed & 39 & 39 & 1.000 & 0 & 0 & & & & \\
\hline Losses & 0 & 0 & \#DIV/O! & 0.0 & 0.0 & & & & \\
\hline $\begin{array}{l}\text { Domestic supply } \\
\text { quantity }\end{array}$ & 8765 & 8251 & 0.941 & 2517 & 2577 & & & & \\
\hline Export Quantity & 7912 & 7912 & 1.000 & 938 & 938 & & & & \\
\hline Stock Variation & 423 & 423 & 1.000 & 54 & 54 & & & & \\
\hline Import Quantity & 3550 & 3550 & 1.000 & 3509 & 3509 & & & & \\
\hline Production & 13550 & 13036 & 0.9620 & 0.0 & 60.3 & & & & \\
\hline
\end{tabular}

${ }^{1}$ For soy drink food supply values, the additional amounts in the protein transition scenario are shown $(-10 \%)$. In the FBS only the protein and food supply quantities had non-zero values $(0.01$ $\mathrm{g} / \mathrm{cap} / \mathrm{d}$ and $0.1 \mathrm{~kg} / \mathrm{cap} / \mathrm{y}$, respectively), but it is not known whether this was soy drink or some other soy product.

${ }^{2}$ For soybean values both those from the original FBS and those with additional soy drink are shown. The additional soybean in Food ( $60.3 \mathrm{ktonnes} / \mathrm{y})$ has been calculated from the additional soy drink in the food supply quantity ( $32 \mathrm{~kg} / \mathrm{cap} / \mathrm{y})$.

${ }^{3}$ All categories from Food up to Production are expressed in ktonnes per year of primary milk (raw milk) and soybean commodities . 


\section{Annex 6 Soy and Feed Crop Parameters (The Netherlands, 2015)}

Table 21 Parameters used in the calculations for the protein transition scenario in The Netherlands.

\begin{tabular}{|c|c|c|c|c|}
\hline Product & Nitrogen & Protein & Fat & Source \\
\hline Soybeans & $6.6 \%$ & $38 \%$ & $18 \%$ & $\begin{array}{l}\text { FAO (food } \\
\text { composition } \\
\text { table) }\end{array}$ \\
\hline Soy drink & $0.61 \%$ & $3.5 \%$ & $2.0 \%$ & $\begin{array}{l}\text { Wikipedia (see } \\
\text { below) }\end{array}$ \\
\hline Ratios & & 0.092 & $0.11^{1}$ & \\
\hline g protein / g N & 5.75 & & & $\begin{array}{l}\text { Timmer \& de } \\
\text { Visser (2014) }\end{array}$ \\
\hline Feed & FCR $^{2,3}$ & DM yield 4 & & \\
\hline Grass & 0.39 & 9.40 & & \\
\hline Silage maize & 0.15 & 15.6 & & \\
\hline Wheat & 0.17 & 8.10 & & \\
\hline Soybean & & 3.00 & & $\begin{array}{l}\text { Verstand et al. } \\
(2020)\end{array}$ \\
\hline
\end{tabular}

${ }^{1}$ Assuming that $100 \%$ of the fat in the soybean is included in soy drink, a share of 0.83 $(0.092 / 0.11)$ can be estimated for the protein of the soybean that ends up in soy drink. 2 FCR: Feed Conversion Ratio in $\mathrm{g}$ feed DM / g milk produced, DM yield in tonnes feed DM per ha. Here, feed DM includes feeding losses in the stable.

${ }^{3}$ Based on a feed efficiency of $1.45 \mathrm{~kg}$ fat and protein corrected milk per kg feed dry matter, $1.06 \mathrm{~kg}$ fat and protein corrected milk per $\mathrm{kg}$ produced milk, dry matter shares in total ration of $50 \%$ grass, $20 \%$ silage maize and $30 \%$ other feed and feeding losses of $5 \%$ for roughages and 2\% for concentrates. Sources: https://edepot.wur.nl/463158, KringLoopWijzer 2019, NZO (2019), Lesschen et al., 2020, Mest en Mineralen, 2015.

4 CBS: Statline, 2015 


\section{Annex 7 Greenhouse Gas Emission Parameters (The Netherlands)}

Table 22 Greenhouse gas (GHG) emission parameters, used in the calculations for The Netherlands case

\begin{tabular}{|l|l|l|l|}
\hline Food item & CFP $^{\mathbf{1}}$ & Remark & Source \\
\hline Milk & 1195 & value of 2018 per kg produced milk & NZO, 2020 \\
\hline Soybeans & 499 & calculated with FeedPrint ${ }^{2}$ & Boer, de et al., 2014 \\
\hline Soy meal & 622 & import from South America & Boer, de et al., 2014 \\
\hline
\end{tabular}

1. CFP: Carbon FootPrint in $\mathrm{g} \mathrm{CO}_{2}$-eq per $\mathrm{kg}$

2. CFP based on inputs for a soybean yield of 2.65 tonnes per ha in the Netherlands In our analysis, lower values for soybean have been used compared to the value from Boer, de et al. (2014) to account for higher soybean yields. We used a yield of 3 tonnes/ha and this would give CFP values of circa $440 \mathrm{~g} \mathrm{CO}_{2}-\mathrm{eq} / \mathrm{kg}$, if the inputs for the soybean cultivation would remain at the same level as reported by Boer, de et al. (2014). However, it is likely that some inputs will increase due to the higher yield level, although less than proportionally. Therefore, the CFP values would fall between 440 and $499 \mathrm{~g} \mathrm{CO}_{2}-\mathrm{eq} / \mathrm{kg}$, and we used the middle of this range (circa $470 \mathrm{~g} \mathrm{CO}_{2}-\mathrm{eq} / \mathrm{kg}$ ) as updated value for reasons of simplicity. If further precision or detail is needed, a new calculation with the present version of FeedPrint could be conducted.

For the avoided GHG emission linked to the co-product of soy drink production, we estimated that $17 \%$ of the original protein in the soybean ( $38 \%$ protein according to the Food Composition Table of the FAO) ends up in the co-product. This means that the additional 60.3 ktonnes of soybeans in the protein transition scenario produces 3.9 ktonnes of soy protein in the coproduct. With a crude protein ratio of $0.464 \mathrm{~g} / \mathrm{g}$ in soy meal (Boer, de et al., 2014), the equivalent amount of soy meal becomes 8.4 ktonnes, which corresponds with an emission of 5.3 ktonnes of $\mathrm{CO}_{2}$-eq in combination with the emission intensity of circa $622 \mathrm{~g} \mathrm{CO}_{2}-\mathrm{eq} / \mathrm{kg}$. 


\section{Annex 8 IPCC N Calculations Ethiopia}

IPCC report findings

Link:

https://www.ipcc-

nggip.iges.or.jp/public/2019rf/pdf/4_Volume4/19R_V4_Ch11_Soils_N2O_CO2.pdf

Constructed table from IPCC report linking terms in formula to elaboration. Green marked parameters are included in the calculations.

\begin{tabular}{|c|c|c|}
\hline Parameters Tier 1 & \begin{tabular}{|l|} 
Description \\
Tier 1
\end{tabular} & Information input parameters \\
\hline FSN & $\begin{array}{l}\text { annual amount of } \\
\text { synthetic fertilizer } \mathrm{N} \text { applied } \\
\text { to soils, } \mathrm{kg} \mathrm{N} \text { yr-1 }\end{array}$ & 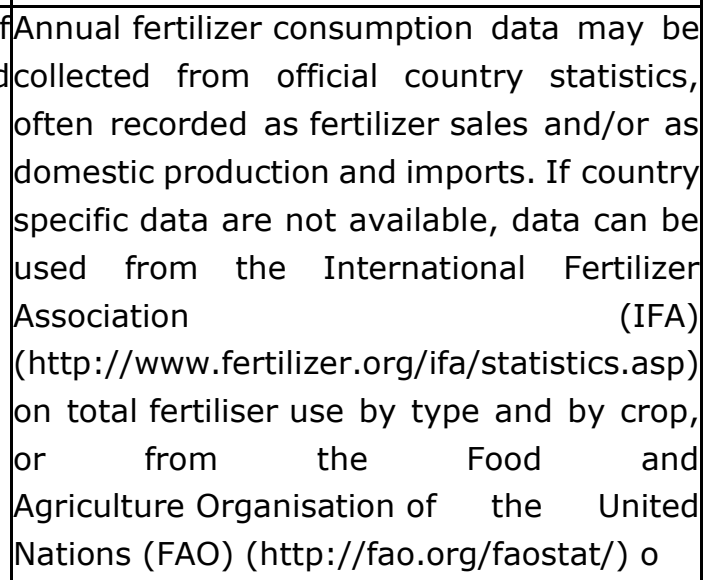 \\
\hline FON & $\begin{array}{l}\text { total annual amount of } \\
\text { organic } \mathrm{N} \text { fertilizer applied to } \\
\text { soils other than by grazing } \\
\text { animals, kg N yr-1. } \\
\text { (Maybe different application } \\
\text { in other scenario). Amount } \\
\text { of fertilizer does not change } \\
\text { with change in animals. Keep } \\
\text { constant in } 10 \%\end{array}$ & $\begin{array}{l}\text { fannual amount of animal manure } \mathrm{N} \text { applied } \\
\text { to soils, kg } \mathrm{N} \text { yr- } 1 \text { (FAM) }+ \text { annual amount } \\
\text { of total sewage } \mathrm{N} \text { (coordinate with Waste } \\
\text { Sector to ensure that sewage } \mathrm{N} \text { is not } \\
\text { double-counted) that is applied to soils, kg } \\
\mathrm{N} \text { yr-1 (FSEW) }+ \text { annual amount of total } \\
\text { compost } \mathrm{N} \text { applied to soils (ensure that } \\
\text { manure } \mathrm{N} \text { in compost is not double- } \\
\text { counted), kg } \mathrm{N} \text { yr-1 (FCOMP) }+ \text { annual } \\
\text { amount of other organic amendments used } \\
\text { as fertiliser (e.g., rendering waste, guano, } \\
\text { brewery waste, etc.), kg N yr-1 (FOOA) }\end{array}$ \\
\hline FAM & $\begin{array}{l}\text { annual amount of animal } \\
\text { manure } \mathrm{N} \text { applied to soils, } \mathrm{kg} \\
\mathrm{N} \mathrm{yr}\end{array}$ & $\begin{array}{l}\text { Amount of managed manure } \mathrm{N} \text { available for } \\
\text { soil application, feed, fuel or construction, } \\
\mathrm{kg} \mathrm{N} \text { yr-1 (see Equation } 10.34 \text { in Chapter } \\
\text { 10) (NMMS Avb) FracFEED = fraction of } \\
\text { managed manure used for } \\
\text { feed, FracFUEL = fraction of managed } \\
\text { manure used for fuel, FracCNST = fraction } \\
\text { of managed manure used for construction }\end{array}$ \\
\hline FCR & 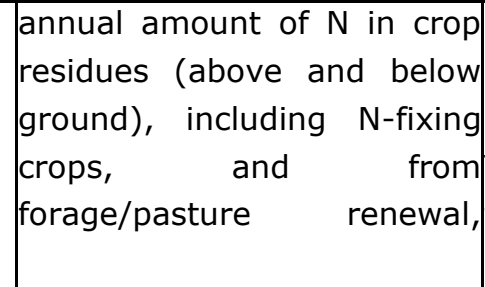 & $\begin{array}{l}\text { annual total amount of above-ground crop } \\
\text { residue for crop T, kg d.m. yr-1.+ N } \\
\text { content of above-ground residues for crop } \\
T, \mathrm{~kg} \mathrm{~N} \text { (kg d.m.) -1 (Table } 11.1 \mathrm{a} \text { ) }+= \\
\text { fraction of above-ground residues of crop T } \\
\text { removed annually for purposes such as }\end{array}$ \\
\hline
\end{tabular}




\begin{tabular}{|c|c|c|}
\hline & 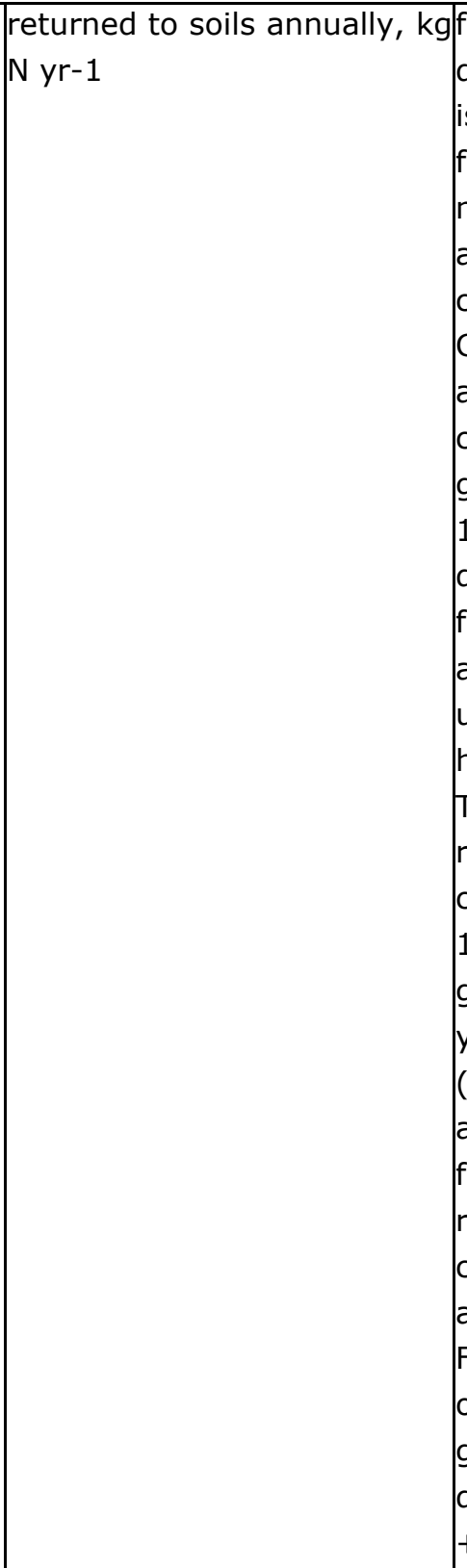 & 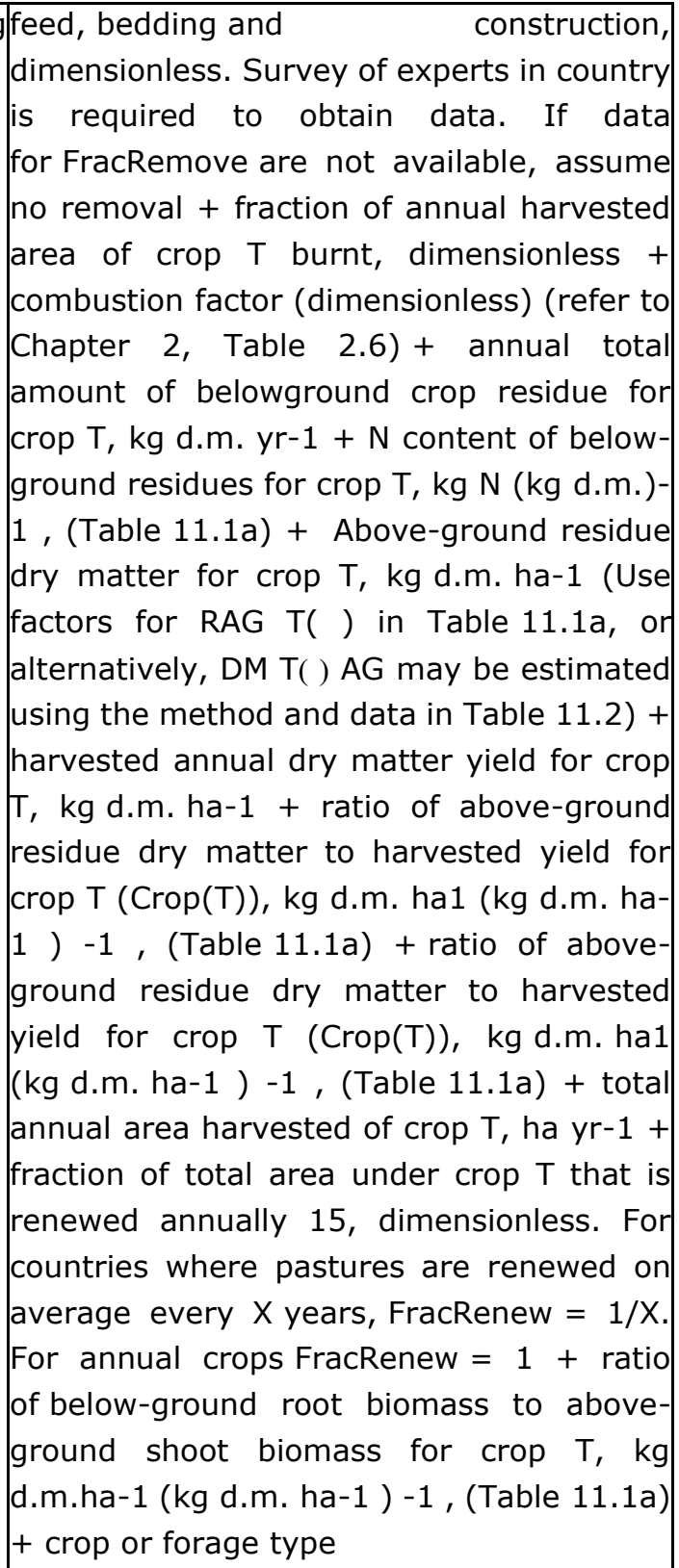 \\
\hline $\operatorname{Crop}(\mathrm{T})$ & $\begin{array}{l}\text { harvested dry matter yield for }= \\
\text { crop T, kg d.m. ha-1 }\end{array}$ & 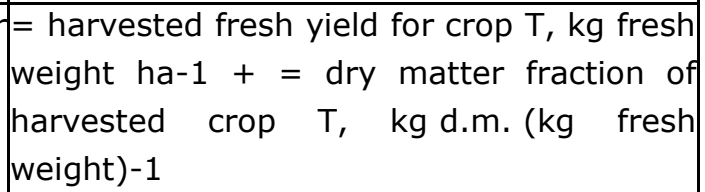 \\
\hline FSOM & $\begin{array}{l}\text { the net annual amount of } \\
\mathrm{N} \text { mineralised in minerall } \\
\text { soils as a result of loss of soill } \\
\text { carbon through change in } \\
\text { land use or management, kg } \\
\mathrm{N}\end{array}$ & $\begin{array}{l}\text { average annual loss of soil carbon for each } \\
\text { land-use type (LU), tonnes } \mathrm{C} \text { (Note: for Tier } \\
1, \Delta \text { CMineral LU, will have a single value for } \\
\text { all land-uses and management systems. } \\
\text { Using Tier } 2 \text { the value for } \Delta \text { CMineral LU, will } \\
\text { be disaggregated by individual land-use } \\
\text { and/or management systems }+\mathrm{C}: \mathrm{N} \text { ratio } \\
\text { of the soil organic matter. A default value of } \\
15 \text { (uncertainty range from } 10 \text { to } 30 \text { ) for the } \\
\text { C: } \mathrm{N} \text { ratio ( } \mathrm{R} \text { ) may be used for situations } \\
\text { involving land-use change from Forest Land } \\
\text { or Grassland to Cropland, in the absence of } \\
\text { more specific data for the area }\end{array}$ \\
\hline FOS & $\begin{array}{l}\text { Alternatively, total areas of } \\
\text { organic soils from each }\end{array}$ & \\
\hline
\end{tabular}




\begin{tabular}{|c|c|c|}
\hline & $\begin{array}{l}\text { country are available from } \\
\text { FAO } \\
\text { (http://fao.org/faostat/), and } \\
\text { expert judgement may be } \\
\text { used to estimate areas that } \\
\text { are drained/managed. For } \\
\text { Forest Land, national data } \\
\text { will be available at soil } \\
\text { survey organisations and } \\
\text { from wetland surveys, e.g., } \\
\text { for international conventions. } \\
\text { In case no stratification by } \\
\text { soil fertility is possible, } \\
\text { countries may rely on expert } \\
\text { judgment. }\end{array}$ & \\
\hline FPRP & $\begin{array}{l}\text { annual amount of urine and } \\
\text { dung } \mathrm{N} \text { deposited on pasture, } \\
\text { range, paddock and by } \\
\text { grazing animals, } \mathrm{kg} \mathrm{N} \mathrm{yr-1}\end{array}$ & $\begin{array}{l}\text { number of head of livestock } \\
\text { species/category } \mathrm{T} \text { in the country }+ \text { annual } \\
\text { average } \mathrm{N} \text { excretion per head of } \\
\text { species/category } \mathrm{T} \text { in the country, kg } \mathrm{N} \\
\text { animal-1 yr1 (see Chapter } 10 \text {, Section } 10.5) \\
+ \text { fraction of total annual } \mathrm{N} \text { excretion for } \\
\text { each livestock species/category } \mathrm{T} \text { that is } \\
\text { deposited on pasture, range and paddock12 }\end{array}$ \\
\hline
\end{tabular}

FCR calculations

\begin{tabular}{|l|l|l|l|}
\hline Data & Scenario A & & $\begin{array}{l}\text { Scenario } \\
\text { B + C }\end{array}$ \\
\hline Average production cereals & 2.5 ton/ha & & \\
\hline Average production soy & 2.3 ton/ha & & \\
\hline Cereal production & 25884 & ktonnes/y & 23996 \\
\hline Soy production & 98.3 & ktonnes/y & 599 \\
\hline DRY soy & 0.91 & & 0.91 \\
\hline DRY cereals & 0.88 & & 0.88 \\
\hline CROP $(T)$ cereals & 2.2 & & 2.2 \\
\hline CROP $(T)$ soy & 2.093 & & 2.093 \\
\hline R AG T cereals & 1.3 & & 1.3 \\
\hline R AG T soy & 2.1 & & 2.1 \\
\hline AGDM T Cereals & 2.86 & & 2.86 \\
\hline AGDM T Soy & 4.3953 & & 4.3953 \\
\hline RST cereals & 0.22 & & 0.22 \\
\hline RST soy & 0.19 & & 0.19 \\
\hline Area cereals & 10353600 & ha & 9598400 \\
\hline Area soy & 42739.1 & & 260434.8 \\
\hline N BG T cereals & 0.009 & & 0.009 \\
\hline N BG T soy & 0.008 & 0.008 \\
\hline N AG T cereals & 0.006 & 0.006 \\
\hline N AG T soy & 0.008 & 0.008 \\
\hline BGRT cereals & 11525627.52 & 10684939 \\
\hline & & & \\
\hline
\end{tabular}




\begin{tabular}{|l|l|l|l|}
\hline BGRT soy & 52687.817 & 321058 \\
\hline AGRT cereals & 29611296 & $\begin{array}{l}\mathrm{kg} \mathrm{d.m.} \\
\mathrm{yr}-1\end{array}$ & 27451424 \\
\hline AGRT soy & 187851.3 & $\begin{array}{l}\mathrm{kg} \mathrm{d.m.} \\
\mathrm{yr}-1\end{array}$ & 1144689 \\
\hline FCR cereals & 281398 & $\mathrm{~kg} \mathrm{~N} / \mathrm{y}$ & 260873 \\
\hline FCR soy & 1924 & $\mathrm{~kg} \mathrm{~N} / \mathrm{y}$ & 11726 \\
\hline
\end{tabular}

\section{EQUATION 11.1}

DIRECT $\mathrm{N}_{2} \mathrm{O}$ EMISSIONS FROM MANAGED SOILS (TIER 1)

$$
\begin{aligned}
& \mathrm{N}_{2} \mathrm{O}_{\text {Direct }}-\mathrm{N}=\mathrm{N}_{2} \mathrm{O}-\mathrm{N}_{\text {Ninputs }}+\mathrm{N}_{2} \mathrm{O}-\mathrm{N}_{\text {OS }}+\mathrm{N}_{2} \mathrm{O}-\mathrm{N}_{P R P} \\
& N_{2} O-N_{\text {Ninputs }}=\left[\begin{array}{l}
{\left[\left(F_{S N}+F_{O N}+F_{C R}+F_{S O M}\right) \bullet E F_{1}\right]+} \\
{\left[\left(F_{S N}+F_{O N}+F_{C R}+F_{S O M}\right)_{F R} \bullet E F_{1 F R}\right.}
\end{array}\right] \\
& N_{2} O-N_{O S}=\left[\begin{array}{l}
\left(F_{O S, C G, T \text { emp }} \bullet E F_{2 C G, T e m p}\right)+\left(F_{O S, C G, T \text { rop }} \bullet E F_{2 C G, T \text { rop }}\right)+ \\
\left(F_{O S, F, T \text { emp }, N R} \bullet E F_{2 F, \text { Temp }, N R}\right)+\left(F_{O S, F, T \text { emp }, N P} \bullet E F_{2 F, T e m p, N P}\right)+ \\
\left(F_{O S, F, T \text { rop }} \bullet E F_{2 F, \text { Trop }}\right)
\end{array}\right] \\
& N_{2} O-N_{P R P}=\left[\left(F_{P R P, C P P} \bullet E F_{3 P R P, C P P}\right)+\left(F_{P R P, S O} \bullet E F_{3 P R P, S O}\right)\right]
\end{aligned}
$$

\section{EQUATION 11.6 (UPDATED)}

N FROM CROP RESIDUES AND FORAGE/PASTURE RENEWAL (TIER 1)

$$
\begin{gathered}
F_{C R}=\sum_{T}\left\{\left[A G R_{(T)} \bullet N_{A G(T)} \bullet\left(1-\operatorname{Frac}_{\mathrm{Remove}(T)}-\left(\operatorname{Frac}_{\text {Burnt }(T)} \bullet C_{f}\right)\right)\right]+\left[B G R_{(T)} \bullet N_{B G(T)}\right]\right\} \\
N_{2} O_{(A T D)}=N_{2} O_{(A T D)}-N \bullet 44 / 28 \\
B G R_{T}=\left(\operatorname{Crop}_{(T)}+A G_{D M(T)}\right) \bullet R S_{(T)} \bullet \operatorname{Area}_{(T)} \bullet \operatorname{Frac}_{\text {Renew }(T)} \\
A G_{D M(T)}=\operatorname{Crop}_{(T)} \bullet R_{A G(T)}
\end{gathered}
$$


Wageningen Environmental Research P.O. Box 47

6700 AA Wageningen

The Netherlands

$\mathrm{T}+31(0) 317480700$

www.wur.nl/environmental-research

Wageningen Environmental Research Report

ISSN 1566-7197

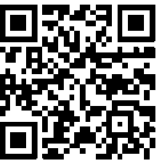

The mission of Wageningen University \& Research is "To explore the potential of nature to improve the quality of life". Under the banner Wageningen University \& Research, Wageningen University and the specialised research institutes of the Wageningen Research Foundation have joined forces in contributing to finding solutions to important questions in the domain of healthy food and living environment. With its roughly 30 branches, 6,800 employees $(6,000 \mathrm{fte})$ and 12,900 students, Wageningen University \& Research is one of the leading organisations in its domain. The unique Wageningen approach lies in its integrated approach to issues and the collaboration between different disciplines. 